\title{
Inquisição, pacto com o demônio e "magia" africana em Lisboa no século XVIII
}

\section{Didier Lahon}

Em 1787, algumas "negras bruxas" vivem nas cavernas das ribeiras íngremes do Tejo. Para sobreviverem, dizem a sina e vendem sortilégios contra mal efícios. W illiam Beckford, durante um passei o, assistiu à detenção pelal nquisição de uma destas "miseráveissibilas[...] hediondo ser, cujos uivos (o) encheram de terror". ${ }^{1}$ Por si só, o testemunho do famoso dândi inglês não permite afirmar a existência de uma importante bruxaria africana em Lisboa no fim do século XVIII. N o entanto levanta a questão das práticas mágicas na população negra da capital ea possibilidade dequetraços e crenças de origens africanas tivessem sobrevivido, adaptando-se e inserindo-senas práticas locais. Pouco conhecidos, menosestudadosainda, sob o ângulo desta problemática, acrescentar-se-iam então aos elementos desse "rio submerso que terá sido em Portugal a heterodoxia, o descontentamento, a marginalidade, mesmo a heresia, que se opuseram, numa resistência de séculos, ao domínio das consciências, àintolerância, à perseguição, ao ostracismo". 2

O sarquivos da I nquisição constituem neste campo a principal senão a única fonte à qual podemos recorrer. Contudo, esta não se presta facilmente ao exame da heterodoxia considerada do ângulo que aqui nosinteressa. Com efeito, quando um processo diz respeito a um negro ele perde o caráter de confrontação econômica ou política que, sobre fundo religioso, opõe regularmentea Inquisi ção aos cristãos novos e mouriscos que afirmam a crença dos seus antepassados às vezes até a morte. ${ }^{3}$ Para a I nquisição de Lisboa, entre os processos de escravos e forros, negros e mulatos, residindo em Portugal, os condenados entregues ao braço secular são relativamente raros, em especial quando se tratava debruxaria. Em certos processos, perante a gravidade dos fatos indiciados, a sua qualidade de pagãos 
recém-convertidos pesou em seu favor e a Inquisição parece mesmo demonstrar uma certa clemência. Esta impressão, deixada por vários processos, precisa ser verificada pela análise de um maior número de situações.

Assim, nos casos que conhecemos, a suspeita de um regresso à religião dos antepassados nunca foi explicitamente indicada, mesmo quando a acusação era a de ter negado a Fé católica. N unca aparece o termo idolatria, nunca é feita uma referência explícita às crenças africanas. M esmo tardiamente, em 1796 por exemplo, quando o escravo Lourenço é denunciado por adorar freqüentemente o sol à vista de toda a vizinhança, embora seja "cristão batizado". ${ }^{4}$

U m negro, quer africano, quer natural da metrópoleou do Brasil, era tratado como um cristão velho: respeitou ou transgrediu as regras edogmas da religião eda igreja. 0 satos quelhesão imputados são considerados como cometidos sob a influência do demônio com quem o acusado teria feito um pacto, pois, como observa José Pedro Paiva ${ }^{5}$ no seu estudo sobre os séculos XVII eXVIII , a ideologia do pacto diabólico foi objeto de uma verdadeira propaganda.

D os púlpitos pela voz de alguns párocos e missionários, dos confessionários, nas igrejas onde os exorcistas atuavam, dos pal cos onde se liam sentenças dos autos-da-fé os populares foram bombardead os com a mensagem da filiação diabólica dos actos mágicos. N em sempreé possível confirmar através dos relatos dos réus a influência desta "propaganda" nas suas narrativas, mas em alguns casos essa influência é evidente e até confessada.

O sinquisidores procuravam de maneira obsessiva o menor sinal desse pacto com o diabo. Esperavam ou desesperavam de ouvir a sua confissão seguida do sincero arrependimento, as duas vertentes de um processo às quaiso acusado devia submeter-se esem as quais el enão podia esperar o seu perdão, a salvação da sua alma, a reintegração na comunidade espiritual e, num plano mais prosaico, a redução do seu castigo corporal.

Em inumeráveis casos, para os inquisidores, o pacto com o demônio constituiu o único fio condutor da instrução do processo, o único filtro que permitia analisar a lógica dos acontecimentos e do comportamento do réu. Se as práticas de bruxaria, de adivinhação ou de curas mágicas, as cartas de tocar ou as bolsas, nomeadamente de mandinga, entravam nesta 
categoria, a blasfêmia, em al gumas circunstâncias, podia igualmente ser do domínio demoníaco. Com este condicionamento, a maior parte das vezes, os el ementos da confissão dos acusados já estavam contidos nas perguntas dos inquisidores ${ }^{6}$ Ser ou não ser um bom cristão, ter conservado a sua Fé apesar de um delito mais ou menos grave, ter-se mais ou menos apartado da religião católica constituíam os temas recorrentes dos interrogatórios. $\mathrm{Na}$ maioria dos casos, 0 acusado entrava no molde que lhe era imposto, quer por medo, tivessesido ou não torturado, quer por compreender queera do seu interesse. Aqui, como em outros lugares da Europa, sob a tortura ou para satisfazer os inquisidores, os acusados confessaram fatos e eventos materialmente impossíveis, prestando-se mais ou menos conscientemente aos quadros teológicos da demonologia.

Em Bruxaria eSuperstição, entre as centenas de processos da I nquisição de Lisboa analisados por José Pedro Paiva, entram uma dúzia de casos de negros e negras por nós estudados. Relativamente a esta população e mais al guns casos das Inquisições de Évora e Coimbra, J. P. Paiva chega a uma constatação particularmente significativa. A pesar da obsessão da Inquisição de conseguir a confissão de um pacto com o demônio, há "da parte dos rústicos uma grande obstinação em não confessarem os pactos diabólicos." E sem essa "prova" os juízes não podiam aplicar sanções mais "pesadas". Assim, apenas 12,6\% dos acusados terminaram por confessar o pacto, mas perto da metademediantetortura. No entanto, mesmo confessando o pacto, "não afirmavam de seguida a sua renegação de D eus e da I greja" porque "a interiorização da crença em D eus era tão sólida que era quase impossível admitir a sua negação". Pelo contrário, no que diz respeito aos negros escravos e forros, J. P. Paiva nota "a tendência para, muitas vezes logo às primeiras perguntas dos inquisidores, confessarem o pacto ea adoração do Diabo ser muito mais facilmente admitida do que entre a população branca, cristã-velha", o que o autor explica por "um compreensível menor enraizamento da crença e discurso católico por parte destes extratos da população". ${ }^{7}$ À esta constatação, que corresponde à nossa própria análise, acrescentaremosa mesma freqüenterecusa de confessar a renegação de D eus e da I greja. Ainda assim, quando a renegação era admitida, aliás freqüentemente por ter sido feita perantenumerosos testemunhos, ${ }^{8} 0$ acusado tentava encontrar uma desculpa num estado de paixão momentânea 
que pudesse atenuar a sua cul pa eafirmava a sua adesão a todos os cânones da I greja, mesmo quando os seus conhecimentos doutrinais revelavam-se muito fracos. Portanto, mesmo sem terem interiorizado como os brancos a crença em D eus, "e o ódio ao D iabo, símbolo de todo o mal, [que] haviam sido tão insistentemente vincados pela pastoral da I greja”, os negros, para J. P. Paiva, parecem ter compreendido a tática que deviam adotar frente aos inqui sidores. Já habituados a dobrar-se à vontade do senhor nos detaIhes do seu quotidiano, sabiam que não podiam entrar numa luta perdida de antemão contra esta instituição temida, inclusive por aquelesque os dominavam habitualmente. 0 sfreqüentesautos-deféincitavam rapidamente os recém-chegados a esta prudência.

Contudo, não se deve generalizar. Certos acusados recusavam não somente confessar a renegação de $D$ eus como de ter feito um pacto com 0 diabo. Alegavam a sua ingenuidade, ${ }^{9}$ pretextando não saber que o que lhes era censurado podia ser atribuído ao demônio. A esse respeito, durante os interrogatórios, al guns réus refutavam as acusações com um surpreendenteeduradouro autodomínio. M astal pertináciararamente conseguia agüentar por muito tempo as longas, repetitivas e debilitantes sessões de interrogatórios contraditórios. N o caso contrário, a tortura apagava geralmente qual quer veleidade de resistência prolongada.

Se é certo, como afirma J. P. Paiva, que os acusados brancos conheciam a "cultura da organização" e sabiam que confessar abertamente o pacto diabólico ou a renegação de D eus era contrário ao seu interesse, não há a menor dúvida quemuitosnegros não a ignoravam. Caso contrário, muito rapidamente, a sua permanência nos cárceres da Inquisição permitia-lhes compreender os seus principais mecanismos. A esse conhecimento, mesmo que intuitivo, juntava-se uma espécie de cegueira ou surdez ideológica da parte dos inquisidores, que causa dificuldades aos investigadores para encontrar os elementos abertamente africanosnas confissões. Q uer osacusados não os confessavam como tais, quer os escrivães não os transcreviam fielmente, reduzindo-os a manifestações de ordem diabólica compreensíveis a uma mentalidade ocidental pouco preparada para perceber as crenças africanas de outro modo que como idolatria de origem demoníaca. 


\section{"Socorro, meu Diabo": o recurso dos humilhados}

Todavia, alguns processos deixam transparecer um fundo africano. J. P. Paiva não deixou de sublinhá-lo a respeito de $C$ atarina $M$ aria, ${ }^{10}$ natural de Angola, escrava de um Beneficiado particularmente violento e de duas mulheres doentiamente ansiosas. O bserva, com efeito: "as palavras que proferia, se o notário não as deturpou excessivamente, tinham pouco a ver com as ditas por feiticeiras lusas [... ]", e insiste num fato que observamos igualmente:

na Inquisição de Lisboa, este tipo de delito de escravos que devido a maus tratossequeriam vingar deseus senhores, conheceu significativo crescimento durante o século XVIII , (... ), na mai oria dos casos, eles confessavam que para tal fim usavam palavras para convocar "o diabo" para queesteosviesse auxiliar, prática da qual não existe eco entre os feiticeiros naturais do continente. ${ }^{11}$

0 processo de $C$ atarina $M$ aria nos permite suspeitar de uma forte ligação com a África. 0 seu caso é exemplar, porque prova quealguns escravos, dos dois sexos, eram já portadores de conhecimentos tradicionais apesar de quase crianças naaltura do seu cativeiro. $N$ aturalmente, como observa $M$ anuel $M$ oreno Fraginals, seno âmbito da escravidão os "africanos muito jovens não teriam sido portadores de conhecimentos culturais muito elaborados", no entanto, de acordo como R. Slenes, "eles já teriam assimilado as orientações culturais básicas", constatadas por vários autores numa vasta zona da África central. Além disso, sublinha ainda R. Slenes, não se podeter como um fato adquirido que, mesmo retirados da sua cultura de origem na adolescência, os jovens africanos sofressem um processo de "desaculturação" rápido eincorporassem os model os culturais europeus. ${ }^{12}$ U ma primeira socialização, uma primeira aprendizagem podia ser completada em cativeiro por um escravo mais antigo, como aconteceu com Catarina M aria. Assim, apesar de uma provável alteração, laços suficientemente fortes com a cultura materna podiam ser preservados.

D eixemos um momento o caso mais complexo de $C$ atarina $M$ aria em proveito do de Florinda M aria, ${ }^{13}$ também natural da Angola. Como freqüentemente acontecia, Florinda $\mathrm{M}$ aria tornou-se feiticeira depois de ter sido violentamente castigada por sua senhora. Com pedaços de pano pre- 
to ela fabricou uma bonequinha na qual espetou uma dúzia de agulhas. A boneca, amarrada com cordas de viola, foi escondida embaixo do colchão da senhora, que rapidamente viu a sua saúde declinar. Para perfazer a sua obra, Florinda $M$ aria não hesitou em colocar um veneno na sopa de sua patroa. Logo, esta começou a sofrer de repentinas crises de asma e procurou o remédio nos exorcismos de um padre que, após o malogro do seu tratamento espiritual, terminou por Ihe administrar uma infusão apresentada como um contraveneno. D enunciada, Florinda M aria confessou imediatamente obter os seus conhecimentos das mulheres do seu paíse, numa outra sessão, de seu pai.

O caso de C atarina M aria éainda mais significativo. Q uando caiu nas mãos da I nquisição, ela tinha 17 anose já havia sido vendida quatro vezes. A primeira no Rio de Janeiro, quando chegou da África, com dozeanos de idade. Seu dono, um soldado, mandou batizá-la e, quando voltou para Lisboa, vendeu-aa uma mulher com quem elaficou por pouco tempo. Com seu novo senhor, um comerciante de Santarém, ela permaneceu por três anos durante os quais apren deu a doutrina cristã e começou a confessar-se. Q uando entrou na casa do Beneficiado passou a freqüentar a igreja, assistia à missa - durante a qual, quase sempre adormecia, denunciou uma testemunha - , e confessava-se. M as, pretextando que el a não conhecia a doutrina, o padre recusava-Ihe a comunhão. N o entanto, constatou-se que ela recitava com perfeição todasas orações, conhecia osmandamentos dal greja e explicava o mistério da Santíssima Trindade, conhecimentos que a colocavam muito acima da maior parte dos cristãos velhos da sua época. Com tal educação religiosa, ela não podia al egar ignorância para justificar osseus atos. Chamado a testemunhar contra $\mathrm{C}$ atarina $\mathrm{M}$ aria, o comerciante de Santarém afirmou nunca ter constatado nela os fatos extraordinários que Ihe eram censurados. M as recordou-se que a sua mulher tropeçara e caíra várias vezes, sem saber porque, e torcera duas vezes o tornozelo. Também Ihe acontecera o mesmo incidente mas, na época, não Ihe dera qualquer importância. Por conseguinte, foi aparentemente quando ela entrou na casa do Beneficiado, onde assistia havia já quinze meses na altura da denúncia, que todos os poderes do M aligno desencadearam-se e levaram Catarina $M$ aria a cometer um conjunto de atos que conduziram os ocupantes a um estado característico de histeria e paranóia, preexistente indubitavelmente 
à sua chegada. Com efeito, meses antes o Beneficiado tinha denunciado a sua criada branca, Josefa M aria, acusando-a de ter enfeitiçado a sua casa após ter celebrado um pacto com o demônio e mantido relações sexuais com ele. Q uando $C$ atarina $M$ ariafoi julgada, acusada decrimes semelhantes aos da outra criada, esta encontrava-se em Angola, para onde, embora reconciliada, tinha sido degredada. C atarina M aria foi acusada de pacto com o demônio, apesar denão ter confessado, ede manter relações sexuais contínuas com ele, que teria sido o responsável pelo seu desfloramento, "confirmado" por exame. H averia um ano que estaria lançando mal efícios sobre a casa onde, de noite, ressoavam barulhos inexplicáveis. Além disso, a ama do Beneficiado e a filha dela começaram a sofrer de repentinas dores nos dentes, nas orel has enos ol hos, sentiram debilidades e apatias inexplicáveis que, afirmaram, apareciam e desapareciam de acordo com o bom ou mal querer da escrava que, por último, tentou envenenar toda a casa. Entretanto, apesar detodos os esforços de $C$ atarina $M$ aria e da sua associação com o demônio, a saúde do seu senhor não foi abalada. Ele resistiu a seus malefícios porque, segundo $C$ atarina, a sua Fé era bem maior que a das duas mulheres.

0 interesse da confissão de $C$ atarina $M$ aria diz respeito a suas relações com o seu passado, com a sua terra natal. Ela confessou ter mantido relações sexuais com o diabo, "na figura de pretinho", desde o seu embarqueem Angola, eque as primeiras palavras para realizar malefício, "carinca casundeque carisca", foram-Ihe ensinadas pelo seu pai C atumbeque e a seguir, em Lisboa, por uma negra de nome Ana. Além disso, regularmente, no espaço de uma hora, o diabo levava-a para Angola onde encontrava a antiga criada da casa, que nunca tinha encontrado anteriormente. Esta última, de noite como de dia, acompanhada de um diabo que tinha a aparência de um negro ou mais raramente de um mulato, regressava às vezes de Angola à casa do seu antigo patrão e ficando nela por muito tempo incitava C atarina M aria a fazer todo o mal possível.

Assim, graças ao seu diabo, C atarina M aria viajava de volta para Angola. A travessava o mar e realizava no sentido contrário a viagem que a tinha separado da sua terra natal e dos seus. M as ela não diz se, nessas ocasiões, encontravam-se. No entanto, entre todos os processos analisados, CatarinaM ariaéaúnicaescravaafricana capaz dereconstituir asuagenealogia, de dar na sua língua materna o nome dos seus pais e de suas irmãs. ${ }^{14}$ 
$\mathrm{N}$ as confissões dos acusadosnegros, os diabos são freqüentementepretos. 0 quenão surpreendia aos inquisidores mas apenas confirmava as suas certezas. No entanto, freqüentemente acontecia que o "diabo" do negro fosse branco, com aparência de mulher. Estas diferenças cromáticas e de gênero, de acordo com os indivíduos e o contexto queel es descreviam, não podem ser consideradas como detalhes sem significados simbólicos. $\mathrm{Da}$ mesma maneira, aceitar o termo de diabo para qualificar as figuras pretas ou brancas que se apresentavam aos acusados ou os acompanhavam, seria adotar o ponto de vista do inquisidor. Seria admitir, como se fosse uma evidência, que todos os escravos africanos ou naturais do reino, mulatos incluídos, tinham interiorizado a cor preta como símbolo erepresentação do mal. ${ }^{15}$

O ra, na cultura dos povos da região do Congo-Angola, o branco é o símbolo da morte: os homens são pretos, os espíritos são brancos. Além disso, apoiando-se sobre os trabal hos de M acG affey, R. Slenes ${ }^{16}$ sublinha que nesta região da África o tráfico de escravos era considerado como uma viagem para a morte, eque a terra dos brancos era identificada como a dos mortos. M acG affey recorda que os Bakongo acreditavam, há pouco ainda,

que os mortos vão para América (concebido como um composto da Amé rica e da Europa) e sempre foram. 0 fato histórico do tráfico de escravos é recordado como uma forma de bruxaria, pela qual um grande número de Africanos foi transportado para a outra "costa".

O sescravos acreditavam no regresso do seu espírito para aÁfrica após a sua morte, assim como na possibilidade de voltar em espírito, mesmo que ainda vivos, voando à maneira de um feiticeiro. Além disso, para 0 Brasil, $M$ aria K arasch ${ }^{17}$ sublinhou a freqüência dos escravos que, se desesperando de voltar vivos à África, suicidavam-se por afogamento, forma de "batismo" quelibertava a sua alma para a travessia para a África. É necessário recordar também os numerosos cativos que se lançavam ao mar durante as travessias para as Américas.

Assim, apesar de falar perfeitamente o português, como real ça o familiar do Santo 0 fício, C atarinaM aria não se satisfazia em praticar a feitiçaria de acordo com uma fórmula africana aprendida com seu pai e comple tada em Portugal. Graças ao seu diabo preto/negro, retornava regularmenteà África e mantinha relações com uma exilada branca cujo diabo era igual- 
mente preto/negro, mas às vezes desta cor intermédia que é o pardo. Se a travessia da água, do mar, se o elemento líquido em geral, possuía este valor simbólico de regresso às origens, temos que nos perguntar sobre o sentido a dar ao "desejo de suicídio", lançando-se num poço, como fez Joana Antônia, ${ }^{18}$ natural da Angola, com 8 anos de idade na época. Um desejo que se teria transformado num pedido deajuda ao "demônio", com quem, numa tão tenra idadee sem dúvida ainda pou co conhecedora do seu significado cristão, teria firmado um pacto. É necessário interrogar-seigualmente sobre a associação feita com o mesmo, aos 12 anos, por M aria de Jesus, ${ }^{19}$ natural deLuanda. Aos 28 anos, jáforra emorando no H ospital daTerceira O rdem de S. Francisco, graças a um legado deixado a esta instituição pela sua senhora, confessa entre outras faltas as suas desl ocações noturnas com o demônio. 0 diabo, bonito de rosto, mas feito de madeira e muito torto, aparecia na forma de um homem, sem cor, ou de uma mulher, ou ainda como um cavalo ou um camelo: "e se lhe mostrava posto em hum oratório na figura de C risto como em cruz, outra vezes no mesmo oratório na figura de camelo". O utras vezes, após ter-Ihe untado a parte da frente do corpo com um ungüento o diabo a fazia passar

em camisa, ena água, (... ) sobrea outra margem (...) via efectivamente que passava o mar, mas não compreendia como estava sem sapatos, e sentia efectivamente a água e sentia a camisa, ena água molhada parecia-Ihe passar o mar como se aquilo tivesse sido uma pequena corrente de água.

D izia-lheo demónio queiam apenasaté M oita, do outro lado do Tejo, distante algumas léguas ao Sul de Lisboa. Lá, numa quinta com hortas,

estavam esperando cinco o seis D emônios em figura de homens, e outras tantas mulheres, e todos se punham a bailar com castanholas, abraçavam e beijavam as mulheres, (... ), e no fim da dança cada hum dos D emônios tinha cópula com sua mulher e com ela só a tinha o D emônio que a acompanhava no sexo de homem, porque muitas vezes se tratava com ela torpe, e lascivamente como mulher.

Este processo, de acordo com Laura de M ello e Souza, é um dos raros da Inquisição portuguesa do século XVIII que faz explicitamente referência ao sabá. 0 ra, estes, em quatro casos sobre seis, referem-se a indivíduos 
"relacionados, de uma forma ou de outra, com o universo colonial". ${ }^{20}$ Sob a pressão da Inquisição, diz ela em substância a propósito de um outro caso sobre o qual voltaremos, a crença (tradicional) cedelugar a um imaginário defundo europeu cuja familiaridade poderia ter sido adquirida nas prisões do Santo 0 fício. 0 que a conduz a interrogar "por que curiosos mecanismos aculturadores teria o imaginário desses negros africanos, al guns com passagem pelo Brasil, se mostrado mais permeável a concepções européias milenares do que o de outros réus portugueses do Santo O fício". O sabá, sugeriu, não teria sido já na época um "discurso banalizado, um estereótipo desprovido de conteúdo, ridicularizado pelas el ites ilustradas da Europa, - passível, nesta qualidade, de ser deslocado para outros contextos?"21 Essa hipótese, aliás recentemente confirmada, ${ }^{22}$ satisfaz contudo apenas parcialmente no caso das declarações de $\mathrm{M}$ aria de Jesus. $\mathrm{N}$ elas dois pontos não correspondem aos estereótipos. N ão somente ela não entrou no modelo tradicional ocidental do transporte ao sabá - o vôo - como introduziu um elemento desconhecido no bestiário diabólico: o camelo. 0 ra, este, no 0 cidente, ao contrário do cavalo, não figurava entre os símbolos relacionados com o D iabo. Representa isto sim um companheiro do homem conduzindo-o de oásis em oásis e permitindo-o atravessar o deserto, símbolo ambíguo - perdição e busca do absoluto - mas não necessariamente negativo, ao qual o camelo poderia indiretamente remeter. ${ }^{23} \mathrm{Com} \mathrm{M}$ aria de Jesus, como sempre, os inquisidores preocuparam-se muito mais de provar o pacto individual com o demônio, e as torpezas sexuais que isso implicava, do que associar a este o tema do sabá no qual o elemento da travessia aquática ${ }^{24}$ inscrevia-se tão pouco que "na literatura portuguesa 0 sabá, o vôo e a metamorfose das bruxas são aspectos quase omissos". N 0 entanto, embora pouco freqüente, o mito era conhecido em Portugal pois, "os inquisidores não tinham um pensamento monolítico. $\mathrm{H}$ avia uns mais abertos que outros a estas crenças". ${ }^{25} \mathrm{~A}$ ssim, se M aria de Jesus tivesse sido influenciada pelo estereótipo europeu, fosse ou não aprendido na prisão, não teria deixado de fazer al usão ao vôo, antes que a uma travessia do mar. É esta falha no uso do estereótipo, enquanto todos os outros elementos clássicos do sabá estão presentes, quena nossa opinião confere um interesse específico a sua narrativa. 
0 imaginário dos Africanos teria sido, se seguirmos Laura de M ello e Souza, mais permeável às concepções européias milenares que o da maior parte dos acusados portugueses. Todavia essa permeabilidadenão devenos levar a olhá-los, mais uma vez, como seres humanos simbolicamente lobotomizados por efeito da aculturação, tendo perdido, pelo menos para os de primeira e segunda geração, qualquer memória, qualquer referência às suas origens. $N$ ão étanto a evidente permeabilidade do seu imaginário, melhor dito, a sua colonização, que parece ter que ser questionada mas sobretudo os reduzidos modos de expressão desteimaginário num contexto caracterizado pelo medo e a coação. N esse sentido temos que insistir sobre 0 fato de que os acusados de feitiçaria, quer da metrópole quer das colônias portuguesas e espanholas, fazem abertamente referência ao seu passado africano apenas de maneira muito excepcional.

Por isso, as confissões de C atarina M aria e de Florinda M aria devem ser consideradas de particular interesse para o estudo das populações escravas em Portugal. N ão obstante a raridade de depoimentos desse teor, 0 estado atual das investigações em Portugal não permite concluir que os negros, escravos eforros da metrópole sofreram um processo de aculturação muito mais rápido e profundo que seus companheiros brasileiros que viviam no meio urbano durante os séculos XVIII e XIX. Considerar a repressão inquisitorial como a principal responsável pelo desaparecimento destas sobrevivências seria ignorar ou esquecer que, em Portugal, os "feiticeiros" e outros "mágicos" nunca foram o alvo principal do Santo O fício. ${ }^{26} \mathrm{Além}$ disso, a distinção entre escravos ou forros "portugueses" e "brasileiros" feita unicamentea partir do lugar de nascimento ou de batismo, quando a informação existe, não se revela sempre produtiva. M uitos entre eles podiam sucessiva ou alternadamente pertencer a uma ou outra categoria, e as vezes, às duas. Q uando se fala de permeabilidade, énecessário pôr na balança as influências recíprocas entre a metrópole ea colônia. Por um lado, precisamos considerar o importantíssimo número de escravos da metrópol evendidos no Brasil, quer como forma extrema de castigo quer, depois das leis de 1761 e 1773, ${ }^{27}$ como melhor forma de desinvestimento sem perda de capital. D e outro, cada frota vinda da colônia trazia o seu contingente de escravos; os que seguiam os seus senhores, os africanos quetransitavam pelo Brasil, por último os marinheiros negros, escravos de 
ganho ou forros. Para além dos seus valores culturais e das suas crenças, importavam, abertamente ${ }^{28}$ ou às escondidas, produtos provenientes do Brasil cujo uso veremos logo. Q uanto à África, até 1761, cada desembarque em Lisboa denovos escravos permitia renovar emanter as relações com o continente e a cultura de origem.

É por conseguinte uma verdadeira rede de passadores de valores culturais, materiaise espirituaiscuja existência percebe-sedemaneiraincontestável, embora fugaz e rara nos documentos. A esta corrente de troca ligada ao comércio, temos que acrescentar todos os acusados "brasileiros" da Inquisição, feiticeiros ou curandeiros, remetidos ao tribunal de Lisboa para serem julgados. C umpriam geralmente as suas penas na metrópole, onde costumavam reincidir difundindo as suas práticas antes de caírem novamente nas garras do Santo 0 fício. A esse respeito, longe de viver num universo fechado, num único espaço geográfico e simbólico, os protagonistas dos processos da Inquisição revelam que evoluíam no meio de um processo de mestiçagem cultural complexo no qual são ao mesmo tempo agentes e objetos, como frisou Laura de M ello e Sousa. ${ }^{29}$

Temos que acrescentar que, freqüentemente, nos processos, não são as confissões dos réus que fornecem as informações de maior significado social. São as testemunhas que revelam a exten são das redes de sociabilidade implicando um número considerável de pessoas das quais podemos duvidar da ortodoxia religiosa. Por isso, no estado atual da investigação em Portugal, a ausência provada de um culto coletivo, estruturado e organizado, seguido por uma franja mais ou menos importante de africanos ou negros naturais do reino, não pode surpreender. $E$, mesmo admitindo que tal culto existiu e que fosse só embrionário, é pouco provável que tenha deixado o mínimo vestígio na documentação. Porém, não parece inútil procurar os "estados mentais" que poderiam ter se manifestado, não em um culto de caráter público mas sim, seguindo D urkeim, em um pensamento oferecido às divindadestradicionais. ${ }^{30}$ Sem negar todavia a permeabilidade ao modelo ideológico dominante, adaptado e articulado às situações de esperas/desesperos geradas pelas condições do novo meio, assim como o deixam entender os exemplos a seguir. 


\section{Curandeiros e feiticeiros negros de Lisboa Francisco Antônio, negro, gordo, aleijado e curandeiro}

Entre todos os processos, o de Francisco Antônio ${ }^{31}$ é 0 exemplo da dificuldade para distinguir o que na prática de um "mágico" africano diz respeito à tradição ocidental assimilada, embora conservando alguns traços da tradição de origem, tanto no ritual como na cura. Em 1744, quando respondeu às acusações do Santo 0 fício, Francisco Antônio era um forro natural da Costa da M ina, descrito como bastante gordo - hoje seria provavelmente qualificado de obeso - e aleijado de uma perna. Praticava as suas curas com a ajuda de sua mulher, Joana, ede dois acólitos; um era cego enquanto 0 outro tinha uma perna e um braço al eijados. ${ }^{32} \mathrm{~N}$ o Bairro Alto onde morava, assim como na zona próxima do $\mathrm{M}$ ocambo, a sua reputação já não estava por fazer. D ois testemunhos afirmaram que tratava de todas as de espécies de mazelas e moléstias e que não parava de ser chamado. Ele recrutava entre a população negra mas gozava igual mente de uma grande fama junto dos brancos, os únicos que, de maneira sintomática, foram chamados a testemunhar e a confessar neste processo.

Para estes, Francisco Antônio representava o último recurso contra as enfermidades de origem maléfica quando a medicina e os exorcismos faIhavam. D e fato, o processo não deixa dúvida que, uma vez vencidos, médicose religiosos, apósterem posto os seus fracassos respectivos na conta da bruxaria, não tiveram receio de aconselhar aos pobres desamparados "de procurar quem podia o(s) curar" ${ }^{33}$ Assim, quando encontram Francisco Antônio e os seus assistentes, já estão convencidos serem vítimas de um ato maléfico. Por via ora de uma rede local impossível de definir, ora de um antigo cliente satisfeito, ora de um escravo ou de um neófito são orientados para esta nova esperança de cura. 0 segredo está longe de cercar estas práticas. ${ }^{34}$

Embora Francisco Antônio se deslocasseàs vezes ao domicílio dos doentes, praticava geralmente na sua casa do Bairro Alto. Este foi o caso de Bárbara $\mathrm{M}$ ana, mulher de um antigo barbeiro feito taberneiro, aconsel hado por um pedreiro que foi tratado com sucesso. $M$ as, desconfiada, chegando a saber que Francisco Antônio já havia sido chamado pela Inquisição, atormentada pelos remorsos, fomentados sobretudo pelo malogro da 
sua consulta, confessa-se. Instigada por seu diretor de consciência, denunciou à I nquisição aquele em quem tinha depositado todas as suas esperanças de cura após o malogro dos médicos e exorcistas.

Podemos observar a prática de Francisco Antônio graças a várias testemunhas, antigos doentes, todas pertencentes às camadas sociais mais pobres, às vezes pequenos artesãos, ${ }^{35}$ todos moradores de bairros diferentes mas pouco distantes de onde morava o curandeiro. Logo no primeiro encontro ele decidia o preço da cura e nessa ocasião, seguindo a expressão de P. Bourdieu, ${ }^{36}$ comportava-se como um pequeno empresário independente. D efato, na medida em que a soma não era simbólica - uma moeda de ouro - , ele não se relacionava com os seus doentes de um modo muito diferente dos médicos consultados anteriormente.

U ma vez recebida a sua moeda e depois de ter murmurado algumas palavras incompreensíveis, enquanto espreitava com os ol hos arregalados alternadamente o doente e um pedaço de vidro do tamanho duma hóstia, ou um espel ho, deacordo com os testemunhos, Francisco Antônio confirmava a origem do mal. A cura podia então começar seguindo o esquema geral descrito por Bárbara $M$ ana, seu marido e as outras testemunhas.

Após enxaguar as mãos, Francisco Antônio lançava, numa bacia de argila branca cheia de água, o cruzado novo oferecido pelo doente, um rosário de quiros, mais um solto, dois búzios, dois dados eal gumas pequenas pedras pretas, um conjunto de artefatos sem os quais, de acordo com as explicações dadas a Bárbara, "não podia ver nem fazer nada". ${ }^{37} \mathrm{O}$ s seus assistentes faziam então um círculo ao redor da bacia enquanto ele começava a falar na sua língua, indo e vindo, deixando cair da boca fios de baba. O s seus companheiros pareciam que lhe respondiam, demonstrando estarem em comunicação com a bacia agitando-se acima dela. N a fase seguinte, Francisco Antônio retirava da bacia um dos dados, no qual encontravase "uma coisa preta", passava-o sobre os seus ol hos e a sua boca enquanto pronunciava algumas palavras, colocando-o por último sobre a dobra interna do braço do paciente. Logo depois, tirava com os dentes o dado do braço, sugava a parte onde o tinha colocado e, após al gum tempo, cuspia num pequeno recipiente um pouco de humor de cor amarela. Logo a seguir ordenava a um dos seus assistentes para lançar na rua o humor e que- 
brar o recipiente, recomendando-Ihe tomar muito cuidado para não guardar vestígios dele nos seus sapatos.

Bárbara confessou ter sentido um alívio imediato da sua articulação, graças ao qual conseguiu mover livremente o seu braço "que a fazia pade cer tão cruelmente havia meses que nem conseguia dobrá-lo nem levá-lo à boca". M as imediatamente a dor deslocou-se para a polpa do braço e logo depois para o seu rosto. Bárbara tevequesesujeitar a uma nova sessão. D ois dias depois lançou outra vez um cruzado de sorte na bacia. Terminadas as preliminares, Francisco Antônio aplicou sobre o seu braço doente um ungüento por elefabricado ea dor passou do músculo para o pulso. E desta forma ela

serecolheo para casa com animo de não tornar por escrupulosda consciencia sem embargo dos pretos lhe disserem queesperavão por ella dahi a oito dias, edentro nella não sentia mais quea dor no pulso do braço porém como ella não foy no tempo assinalado sahío a dor para o hombro e principiou a maltratala como de antes. ${ }^{38}$

Seu marido, sem dúvida mais convencido que a mulher dos poderes do curandeiro, foi encontrá-lo e explicar-Ihe a situação. Francisco e seus acólitos responderam-Ihesem rodeios que Bárbara estava nesteestado porqueo queria assim eporque não tinha pago o que devia. No entanto, se ela quisesse vir no dia seguintee pagar as suas dívidas, voltaria curada para casa. M elhor ainda, caso Bárbara não pudesse deslocar-se, dariam ao seu marido um ungüento que iria restabelecêla definitivamente. Bárbara recusou "pelo mal que lhe pareceu aquel a forma de cura eescol heu ir se confessar e vir denunciar a esta $M$ esa o quel hetinha socedido e antes quer padecer do queser curada na referida forma". D eixemosa infeliz com os seus escrúpuIos, a sua desconfiança, a sua incredulidade, sem dúvida justificados tanto pelas exigências financeiras de Francisco Antônio quanto pelos poucos resultados obtidos, para analisar as técnicas e os rituais da cura.

De acordo com as narrativas das testemunhas, Francisco Antônio desempenhava o papel de mestre do ritual no qual, segundo as circunstâncias, introduzia al gumas variações. Com alguns doentes não utilizava um espelho para a adivinhação, mas ol hava diretamente nos ol hos do paciente; às vezes acrescentava al guns botões de metal na bacia; uma vez só indi- 
cou a uma paciente o lugar de onde provinha o mal e, à mesma paciente insegura sobre as suas capacidades, afirmou saber curar os malefícios do diabo. $\mathrm{N}$ a sua casa havia uma imagem do C risto crucificado à qual todos manifestavam respeito e adoração. M as só excepcionalmente essa imagem pareceter um papel no ritual. Q uando Francisco Antônio iniciava osencan$\operatorname{tos}^{39}$ na sua língua, os seus companheiros, sentados em redor de uma pequena mesa sobre a qual era colocada a bacia, respondiam na mesma língua, repetindo várias vezes as mesmas palavras. Eles acompanhavam-no batendo com os dedos sobre a mesa. Às vezes Francisco Antônio batia palmas em cadência. Era após estes encantos ou invocações que a cura começava. N um caso, a paciente bebia uma bebida, preparada pelo assistente cego, composta de al gumas raízes raspadas e reduzi das na hora a pó, de um ovo batido, de açúcar e aguardente. As vezes, as bebidas eram vomitivas, ou laxativas, com efeito imediato. Francisco Antônio variava os ungüentos em função dospacientes. Para uma mulher natural do campo, fabricou um emplastro com urina aquecida misturada com esterco de vaca que aplicou sobre o membro doente. Para uma outra foi só óleo, enquanto num outro caso contentou-se em esfregar o doente com a água da bacia de adivinhação. Finalmente, no braço direito ou esquerdo de várias pessoas, amarrou com um fino pedaço de pano uma raiz borrifada de sangue de galinha branca, às vezes de um gal o preto ebranco fornecidos pel o doente. N a hora em que amarrava o pano, proferia algumas palavras insistindo para que não fosse tirado pois protegeria dos mal efícios.

Enquanto o modusoperandi dafase deadivinhação parece relativamente estereotipado, a cura revela, tendo em conta de que dispomos apenas de al guns exemplos, uma certa diversidade das práticas e uma adaptação a cada doente. ${ }^{40} \mathrm{~N}$ ota-se, como exemplo desta, o uso do esterco de vaca no caso de uma mulher natural duma zona rural. Todavia, em muitos pontos, tanto o ritual de adivinhação como as práticas curativas deFrancisco Antônio são comparáveis com os métodos dos "mágicos" brancos descritos por Francisco Bethencourt e José Pedro Paiva. A bacia, a água, os dados, os búzios, o vidro, o espelho, as pedras ou sementes enfiadas ou soltas, pertencem ao arsenal aparentementeheteróclito dos curandeiros ou feiticeiros da metrópole. I gual semel hança no que diz respeito à cura propriamente dita. Para além do uso vulgar de produtos de origem vegetal - raízes, óleo (mas não 
o azeite) - , animal - ovo, esterco de boi, sangue - ou humana - urina, saliva -, que neste último caso permite transmitir um dom imanente do curandeiro, ${ }^{41}$ Francisco Antônio sugava a parte doente da mesma maneira que o faziam numerosos práticos em diversas partes do mundo.

No entanto, as declarações das testemunhas revelam que o ritual e a cura diferenciavam-se em vários aspectos das práticas conhecidas no mundo cristão. A começar precisamente pela ausência de referências explícitas a qualquer símbolo ou objeto consagrado da religião católica, sempre utilizados pelos "mágicos" da península. N as curas de Francisco Antônio não há pó de pedra de altar, nem hóstia, nem água benta, nem orações cristãs, nenhuma referência a um santo católico, nenhuma oração deS. M arco ou S. Cipriano. Além disso, a imagem de C risto, apesar das reverências que Ihes são dirigidas, numa única ocasião, não parece entrar como elemento estruturador do ritual. Por último, o sinal da cruz, assinalado igualmente uma única vez, traçado acima de uma das pacientes e acompanhado de algumas palavras, quando da aplicação de um ungüento composto unicamente deóleo, não ésuficiente para concluir que setrata - por definição do símbolo cristão. ${ }^{42}$ Sem dúvida, Francisco Antônio evoca o diabo numa ocasião. M as, em país cristão, podia-se designar diferentemente uma força sobrenatural negativa que conduzia as pessoas a consultá-lo?

Esta quase ausência de referências materiais ao domínio sagrado da religião católica, assim como a ambigüidadequeenvolvea imagem deC risto e o sinal da cruz, constitui o primeiro indício de que Francisco Antônio não tem um perfil comum. Q ue seja assistido e acompanhado durante a adivinhação ea cura não correspondetampouco ao modelo do "feiticeiro" ocidental..$^{43} \mathrm{~N}$ ão é sem significado que os encantos sejam proferidos na língua dos oficiantes, e não em português, como também o modo cantado e ritmado por batimentos das mãosemais geralmentedos dedos sobrea mesa onde descansa a bacia. Isto tudo podia, natural mente, fazer parte da encenação específica própria de cada "mágico" a fim de reforçar a vertente esotérica, impressionar o paciente e por conseguinte a eficácia simbólica detodos os seus atos. Aliás, não é porque Francisco Antônio vivia das suas curas que ele não acreditava possuir certos dons, poder recorrer a certas forças ocultas e manipulá-las.

N enhum dos elementos do processo sugere que Francisco Antônio tenha sido um feiticeiro. Aliás, não foi acusado de lançar malefícios ou de 
praticar a sua arte contra as pessoas. Pelo contrário, uma das testemunhas, curada, evocando todos os oficiantes do ritual acrescentou que nunca pensou "que curavam por arte do demónio" e que o acusado fosse um mau cristão porque, para além de suas reverências à imagem de C risto, ele observou a sua atitude caritativa para com os pobres. No entanto, mesmo sendo mal sucedido, sempre procurava desviar a desgraça. E mesmo assim, a cura que desapontou Bárbara pode ser interpretada como um alívio por deslocação da dor, assim como praticavam os sacerdotes da adivinhação de I fa estudada por Bernard M aupoil. ${ }^{44} \mathrm{C}$ om efeito, seo elemento líquido não entrasse na sua prática, e tendo em conta a natural ambigüidade dos símbolos, seria possível considerar que o seu ritual não passou de um avatar, uma forma alterada e adaptada ao contexto português desta forma de geomancia característica da Costa dosEscravos. Embora a falta deelementos suficientes não permita ir muito além dessa suposição, as características atípicas mencionadas fazem pensar numa imbricação de valores religiosos africanos e de práticas e crenças ocidentais. ${ }^{45}$

\section{As bolsas de mandingas \\ J osé Francisco Pereira: escravo Mina e mandingueiro}

Em Portugal, a utilização de bolsas fazendo função de amuleto já era conhecida desde a I dade M édia. ${ }^{46} \mathrm{M}$ as, a partir do fim do século XVII e sobretudo durante as primeiras décadas do século XVIII, um novo tipo de bolsas começou a difundir-se através de alguns escravos e forros vindos diretamente da África ou depois de ter transitado pelo Brasil. C onhecidas doravante sob o nome de bolsa de mandinga, tinham a fama de proteger contra as feridas de armas brancas ou de fogo e fizeram muito sucesso entrea população negra em razão dos inumeráveis confrontos, rixas eajustes de contas que ensangüentavam as noites da capital. ${ }^{47}$

Longe de serem divulgadas em segredo, elas foram objeto de uma verdadeira campanha publicitária, pois, de acordo com J. Pedro Paiva, alguns dos seus adeptos instalavam-se em lugar público de torso nu e, para provar a sua eficácia, lançavam-se sobre uma espada apontada sobre 0 peito. ${ }^{48} \mathrm{C}$ ontudo, o primeiro processo conhecido pelo uso desta bolsa tem lugar apenas em 1690 erefere-seaum forro, guarda-costas, natural deC abo 
Verde, Patrício de Andrade. ${ }^{49} \mathrm{~V}$ inte e três outros processos seguiram sob esta acusação, um total que não reflete o verdadeiro número dos adeptos da capital e da metrópole. Só para a Inquisição de Lisboa, e unicamente para a população negra ou mulata do continente, as acusações ou denúncias-processos representam perto de $10 \%$ dos 150 processos que conhecemos. ${ }^{50} \mathrm{M}$ as, para medir a importância do fenômeno, é igualmente ne cessário considerar o sem número de denúncias que, provavelmente por essa razão, ficaram quase esquecidas pela Inquisição.

J. P. Paiva nota que "o conteúdo destas bolsas de mandinga não era estrutural mentediferente de as quejá eram utilizadas em Portugal". U ma, tomada a um negro natural dos arredores de Luanda, continha diferentes eindeterminados pós, cabelos, unhas deaves e papéis com orações. A aceitação dessas bol sas pel os habitantes do reino poderia por conseguinte provir dos poderes ocultos que, pensava-se, os escravos traziam das suas "estranhas" terras. ${ }^{51} \mathrm{~A}$ origem da bolsa de mandinga era atribuída aos negros mandingas, denominação genérica imprecisa quedesignava diferentes povos instalados no território mandinga da Alta Guiné. O ra, no fim do século XVII, este território era já influenciado pelo Islã desde muito tempo e, o queprovavelmentetinhasido um talismã tradicional de um povo sem escrita, integrava já caracteres árabes. É o que permite concluir a única descrição africana que conhecemos, feita por Francisco de Lemos Coelho em 1684. ${ }^{52}$

Contudo, nenhuma descrição das bolsas apreendidas pela inquisição menciona qualquer texto escrito em árabe. Pelo contrário, os escritos referem-se a um simbolismo eminentemente cristão utilizado numa outra prática de proteção muito difundida em Portugal, a carta de tocar; um conjunto de "papéis que se deviam usar junto do corpo, para através de esse contacto Ihetransmitirem as suas virtudes protectivas". ${ }^{53} \mathrm{~N}$ el es encontravam-se referências aos objetos contra os quais se pretendia ser protegido; as armas brancas ou de fogo. Continham igualmentediversos grafismos com símbolos da Paixão do C risto "como a cruz, uma escada, lanças, um martelo, brochas, um chicote, uma vara com uma esponja na ponta, dados e uma túnica e finalmente uma série de palavras ou "orações" nas quais se exprimiam as virtudesque se pretendiam alcançar". ${ }^{54}$ Freqüentemente, como nas outras práticas mágicas, as orações recorriam à S. Cipriano eS. M arco. 


\section{J osé Francisco Pereira: entre o terror e o sincretismo}

Entre os processos pelo uso da bolsa de mandinga, um apresenta excepcional interesse por oferecer a enumeração detal hada do seu conteúdo edeter sal vaguardado várias páginas das orações e dosgrafismos quea acompanhava. Trata-se mais precisamente de dois processos, o de oséFrancisco Pedroso, e o de JoséFrancisco Pereira, ${ }^{55}$ natural da costa da M ina, escravo no Brasil antes de vir para Portugal com seu senhor. O s dois processos já foram estudados por Luiz M ott eL aura deM elo eSouza. ${ }^{56}$ Sobre esses casos J. P. Paiva nota rapidamentequeum escravo de Lisboa "dizia participar em 'assembléias' compostas apenas por diabos e homens negros, onde o D iabo os sodomizava"57 enquanto Laura de M elo eSouza considera queos mecanismos "de introjeção da concepção erudita de bruxaria por parte dos réus do Santo 0 fício" 58 teriam levado os dois acusados a confessar detalhadamente o pacto eas relações sexuais com o demônio. D e certo, as confissões de Francisco Pedroso e José Francisco Pereira apenas foram obtidas pela tortura ${ }^{59} 0$ que os conduziu "a delirar sobre as múltiplas possibilidades do coito, que coincidentemente constituíam também o saber demonológico: as relações anais, dolorosas, frias, destituídas de prazer e prenhes de sentimentos culposos". ${ }^{60} \mathrm{C}$ ontudo, embora os interrogatórios fossem orientados essencialmente para conseguir dos réus o reconhecimento do seu pacto com o diabo, as suas confissões contêm alguns elementos que não parecem corresponder a um delírio, provocado pelo medo da tortura ou sob o seu efeito, nem com o mecanismo deintrojecão sugerido por Laura de M ello e Sousa. A confissão de Francisco Pedroso, tal como a de M aria de Jesus, contém al guns detalhes completamente al heios ao esquema tradicional do sabá que, integrados a este, permitiram ao acusado quer aliviar a sua consciência quer satisfazer a espera dos inquisidores. M as deste "delírio" estes retiveram apenas o queesperavam ouvir e correspondia ao caráter das assembléias demoníacas e orgíacas. $\mathrm{N}$ ada, no entanto, na acusação inicial, deixava presumir tal deslize.

Francisco José Pereira era acusado de uma fal ta bastante banal para a época e o lugar: fabrico, uso e comércio de bolsas de mandinga compostas deorações. ${ }^{61} 0$ seu companheiro, JoséFrancisco Pedroso, tinha apenas um papel secundário, executando as ordens do primeiro. Ambos analfabetos, 
recorriam a um terceiro comparsa, escravo de um membro da 0 rdem do Cristo, que copiava ostextosdas orações. Em seguidaJ oséFrancisco Pedroso colocava sub-repticiamente os folhetos embaixo da pedra do al tar da igreja paroquial deS. Paulo.

Ao redor dosmandingueiros gravitavam dois escravos desembarcados com seus donos na última frota vinda do Rio de Janeiro. Três outros, provavelmente implicados na seqüência da divulgação do processo, tinham sido embarcados para a colônia. Entreeles, M iguel, queera escravo, na época dos fatos, do coadjutor da igreja de S. Paulo, cuja pedra de al tar servia de abrigo às orações. Todos tinham comprado uma bolsa a um outro escravo, também de nome José, logo após o seu desembarque. N a sua trouxa, ele trazia al gumas ervas para as quais acreditava que poderia encontrar compradores na capital do Império. Com efeito, entre os ingredientes da bolsa estava uma erva de forte odor, proveniente do Brasil. D etalhe significativo, os dois acusados acabaram por confessar quea tinham recebido do demo eque ela possuía o poder deevitar-Ihes os castigos dos seus sen hore ${ }^{62}$ quando vagueavam à noite pelas ruas. ${ }^{63} \mathrm{M}$ as José Francisco Pedroso resistiu demoradamente antes de admitir qualquer intervenção do demônio na confecção da bolsa. Ele afirmou sua boa fé e tentou fazer uma distinção entre dois tipos de mandingas: aquela que trazia e uma outra, conhecida como mandinga do campo. A primeira, afirmava, não podia ser a obra do Demônio mas de D eus, porque não somente era feita para preservar a vida mas os que a utilizavam podiam entrar nas igrejas e cumprir todos os seus deveres de cristãos. Pelo contrário, a do campo, que afirmou nunca ter tido a vontade de utilizar, necessitava da intervenção do demônio e os que a possuíam não podiam entrar numa igreja. ${ }^{64} \mathrm{~V}$ ários processo $\mathrm{s}^{65}$ relativos a mandingas nos levam a refletir que, nos pensamentos da época, a distinção entre as duas categorias não era totalmente destituída de fundamento. O s inquisidores, aborrecidos por não conseguirem fazer compreender aos acusados que qualquer mandinga podia ser apenas obra do M aligno, ${ }^{66}$ pensaram abalar a defesa de J osé Francisco. Utilizaram um argumento que Ihes pareceu sem dúvida de uma devastadora lógica mas revela os seus preconceitos. Como ele podia pensar que a mandinga era uma coisa de D eus, "dado que via que só os pretos a utilizavam, e com muita precaução e que assim a dita mandinga não podia parecer-Ihe lícita e boa"?67 
Examinemos o objeto do delito. A bolsa, feita de um pedaço de pano branco, continha uma pedra decorisco, um olho-de-gato, enxofre, um pó, uma bala de chumbo, uma moeda de prata de pouco valor, um osso de defunto. Al guns dos componentes tinham de ser enterrados al gum tempo antes de serem colocados na bolsa, enquanto as orações deveriam permanecer vários dias embaixo de uma pedra de altar - pedra de ara - a fim de adquirir o seu poder graças ao sacrifício da missa. ${ }^{68}$

As orações corriam sobre vários fólios cobertos de escritos e de desenhos, em parte traçados com o sangue de frango branco ou preto e às vezes, quando o dinheiro faltava para comprá-los, do braço esquerdo $0^{69}$ de J osé Francisco Pereira. O s escritos, no conjunto bastante ilegíveis, revelam a referência a S. M arco e S. C ipriano e a invocação de numerosos outros santos. Um dos desenhos é composto ao redor de al guns dos elementos da Paixão do Cristo enumerados por J. P. Paiva, sem todavia respeitar realmentea composição tradicional. Em outrosfólios, encontram-seigualmente representações do sinal de Salomão associado a uma cruz e/ou a um coração atravessado por uma flecha, que são assinaladas por José Leite de Vasconcel os em Lisboa no fim século XIX.70 Juntava-se também uma representação das armas da coroa portuguesa, sem a esfera armilar. Estas, como outrossímbolos dedifícil interpretação, sobre os quais voltaremos, têm uma cor castanha provavel mente por terem sido traçados com sangue de frango ou humano. ${ }^{71} \mathrm{~A}$ bolsa e as folhas, dobradas e reduzidas a um formato de cerca de 8 × $10 \mathrm{~cm}$, deviam ser incensadas. D urante a noite de São João, a bolsa era colocada embaixo de um fogo para Ihe conferir uma maior eficácia. Tratava-se por conseguinte, como freqüentemente era o caso, de uma prática mágica que associava dois métodos de proteção que se reforçavam mutuamente: a bolsa, quer seja ou não de mandinga, e a carta de tocar.

Até agora nada nos permite pensar que era uma prática mágica de origem especificamente africana. $\mathrm{N}$ as folhas encontram-se numerosos elementos presentes numa oração portuguesa do século XVII considerada como um remédio para estancar o sangue: oração à SantíssimaTrindade, a São C osme e D amião, a Jesus, à V irgem, afirmação dos dogmas da ressurreição de C risto e da Imaculada C onceição, enfim, de igual maneira que na bolsa de José Francisco, o símbolo da cruz intercalava-se entre as palavras das orações. ${ }^{72} \mathrm{Q}$ uer na oração do século XVII, quer na da bolsa de José 
Francisco, nada na formulação dos textos nos recorda um encanto destinado a convocar o demônio. Porém, a presença do signo de Salomão na bolsa de José Francisco introduz uma ambigüidade, se não uma dúvida. De acordo com Francisco Bethencourt, quando as bruxas invocavam os demônios traçavam este sinal como um ritual de proteção face às forças desencadeadas. 0 símbolo garantia a sua integridadefísica na hora deuma comunicação quegerava riscos perigosíssimos. Algunsfeiticei ros, acrescenta Francisco Bethencout, utilizavam a imagem da $\mathrm{cruz}^{73}$ como equivalente ao signo de Salomão. Contudo, de acordo com a crença popular assinalada por Leite de Vasconcelos, o signo de Salomão tinha val or de proteção contra os atos de bruxaria e mais largamente contra o D iabo. É de resto significativo que os inquisidores não parecem ter-se preocupado com o teor das oraçõesquenão podiam ignorar. Foi sobre osingredientes da bolsa, as suas características individuais e, principalmente, sobre como o conjunto estava carregado de uma temível eficácia, atestada por numerosostestemunhos ${ }^{74}$ em outros processos, que os inquisidores orientaram a acusação. É com efeito por ocasião deste "acondicionamento" que o grupo de homens reunia-se durante a noite e, assim como confessaram, encontravam o diabo que os assistia. Às vezes ocorriam verdadeirasorgias sexuais duranteas quais o diabo mudava não somente de cor como de sexo.

0 espaço onde se realizavam estas reuniões, pode-se mesmo falar de cerimônias, se não de ritual, não é indiferente. José Francisco Pereira designou dois lugares em particular: os campos da C otovia ${ }^{75}$ e o Vale de Cavalinho. Este último, situado bem ao norte da capital, era conhecido desde o início do século XVI como o lugar de ajuntamento predileto dos feiticeiros da capital e de diversas regiões do país. ${ }^{76} \mathrm{~J}$. P. Paiva, para o século XVIII, menciona sobretudo a encruzilhada dos quatro caminhos nos camposde C otovia. Eralá, atrás do convento de esus, queos comparsas enterravam a bolsa. M as as reuniões cel ebravam-se igual mente em dois outros lugares: a encruzilhada de Buenos Aires e o sítio do M ocambo. ${ }^{77} \mathrm{O}$ cruzamento deC otovia, o de BuenosAires, o sítio do M ocambo constituem três pontos relativamente próximos. No início do século XVIII, os dois primeiros ficavam ainda em zonas rurais enquanto o M ocambo, situado sobrea paróquia de Santos, era um bairro popular conhecido com estenome desde o século XVI, por abrigar uma numerosa população negra. O s três 
pontos formam um triângulo e poderiam ter delimitado um espaço simbólico considerado mágico ou consagrado.

Era neste espaço quetinham lugar as assembléias duranteas quais, para além do acondicionamento dos ingredientes da bolsa e das orgias sexuais evocados, a pequena turma de negros entregava-se igual menteà uma espécie de sarabanda "infernal". A pós uma refeição feita de bebida e uvas oferecidas pelo diabo, confrontavam-se com ele ou lutavam entre si com armas demadeira - cachaporra - ou deferro, entoavam cantosafricanos entre os quais al guns na língua da C osta da M ina. ${ }^{78}$ Às vezes matavam um bode, comiam a sua carne e depois iam-se embora levando a sua pele dentro dos seus chapéus como proteção contra as armas brancas. 0 consumo debode intrigou evidentemente a I nquisição. I nterrogado sobre o lugar de consumo desta carne, com brancos ou com pretos, de noite ou de dia, se era fervida ou grelhada, Pedroso respondeu demaneira muito cautelosa. Confessou ter ido várias vezes, de noite, na casa de Pereira onde, em companhia de três outros negros, comeu um pouco de guisado sem saber com que espécie de carne tinha sido preparado.

O conjunto dosfatos descritos, nomeadamenteo caráter coletivo das assembléias com a presença do diabo ou de espíritos malignos, levou a Inquisição a identificar estas reuniões como sabás. M as é verdade, como 0 sublinha L aura de M ello e Souza, que os acusados emprestaram-se de certo modo a esta interpretação. Interrogando a crença dos acusados na autenticidade do pacto com o demônio, ela considera "que a partir do momento em que se opta pela adesão ao discurso que é do inquisidor, mas encontra equivalênciasno imaginário popular, passa-sea acreditar quetudo quanto foi dito aconteceu de fato". O ra, para ela, por trás desta leitura do sabá dissimula-se uma cerimônia africana; "na real idade, tratava-se de al go bem diferente, localizado na raiz da umbanda e dos candomblés atuais: os calundus e os catimbós". ${ }^{79} \mathrm{M}$ as, infelizmente, ela não nos entrega todas as chaves da sua anál ise nem os el ementos do processo sobre os quais apóia a sua conclusão. O ra, tanto os dados do processo como as equivalências prováveis ou as anal ogias relevantes entre os dois sistemas culturais de representações são deveras numerosas para que, satisfazendo o imaginário inquisitorial, as confissões dos réus não tenham entrado em contradição com a sua própria crença ou mesmo com os fatos. 
Antes de examinar os diferentes elementos do processo, que nos levam a compartilhar da conclusão de Laura de M ello e Souza, é necessário recordar que desde o século XVI, apesar das proibições, os escravos de vários bairros de Lisboa reuniam-se para bailar e cantar "a seus modos". É assim legítimo pensar que a partir deste período uma franja das diferentes populações negras eafricanas da capital, com o pretexto de divertimentos, praticava uma forma de culto tradicional. Ao longo dos séculos, lugares como o M ocambo e outros próximos, nomeadamente as encruzil hadas da Cotovia e de Buenos Aires, poderiam ter adquirido um valor sagrado para as populações africanas da capital. Q uanto aos diversos elementos materiais esimbólicos contidos no processo, tentaremos interpretá-los do ponto de vista da cultura da C osta da M ina, da qual eram naturais os dois acusados e al guns dos seus acólitos. Terminaremos com al gumas observações acerca de um dos desenhos da bolsa. M as recordemos que, na geomancia da Costa dos Escravos, os amuletos (Fafo) da adivinhação de fa podem ser comprados sem necessidade de uma consulta prévia e que neles é suficienteinscrever um sinal escolhido em virtude das suas qualidades mágicas. M ais tarde, depois de usados, podem ser revendidos. ${ }^{80}$

\section{Pedra de Ara versus Aroun Ara: as equivalências simbólicas}

O sacrifício deum bodee o seu consumo confirmaram evidentemente paraa Inquisição a sua idéia quanto a ter havido um pacto com o demónio. 0 queexplica porque, para além de duas ou três perguntas, não levou adiante a sua investigação. 0 ra, se no 0 cidente cristão o bode foi assimilado ao diabo, à bruxaria eà luxúria, devido àsua atividadegenésica, naÁfrica perde neste aspecto 0 seu caráter negativo, ganhando freqüentemente o de força tutelar. Assim, na região de origem dos réus, uma lenda relacionada com um dos símbolos secundários da divinação de lfá apresenta esteanimal como fonte de vida devido à luz que difunde, de dia como de noite. 0 seu olho esquerdo representa o Sol, 0 direito a Lua, as estrelas são as suas crianças. ${ }^{81}$ Além disso, entre os 16 signos principais da divinação de Ifá, o bodenunca émarcado por um tabu alimentar e, para os iorubás assim como os fons do Benim, o bode é 0 animal simbólico oferecido, cozinhado no óleo de palma, ao O rixá conhecido como Exú para os primeiros, Legba para os 
segundos. ${ }^{82} 0$ ra, como sabemos, Exú/L egba foi assimilado ao diabo pelos missionários em razão destas características notoriamente fálicas e por ser às vezes representado com chifres no $D$ aomé, ${ }^{83}$ mas provavel mente também porque um culto das encruzilhadas era-Ihe rendido. $\mathrm{N} 0$ imaginário católico, simbolizou tudo o queéa maldade, perversão e abjeção. D eacordo com P. Verger, Exú apresenta "aspectos múltiplos e contraditórios que tornam pouco fácil uma definição coerente". D e caráter irascível, gosta de suscitar as dissensões e as querelas, de provocar os acidentes e as cal amidades públicas e privadas. É manhoso, grosseiro, vaidoso, indecente. Para os fons, com o nome de Legba, assume as mesmas características; "é representado por um amontoado deterra na forma de homem acocorado, agraciado de um falo de grande tamanho". ${ }^{84}$ Porém, Exú não é apenas isto. É igualmente um orixá que, quando tratado com consideração, "se mostra amável e atento". É bom, alegre, dinâmico e finalmente "mostra-se assim como o mais humano dos orixás, nem completamente mau, nem completamente bom". Ele é, diz B. M aupoil a respeito de Legba, o princípio da fantasia ou do azar, o acidente. Sem ele, fa não seria humano. ${ }^{85} \mathrm{D}$ e fato, Exú/L egba, que pode ser um orixá protetor, manifesta a sua extrema efuriosa susceptibilidade apenas quando se esquecem de fazer-Ihe oferendas ou sacrifícios. M atar, ferir, o acidente, a confusão, a cólera súbita, o lapso, o pesadelo, os sonhos eróticos e a loucura momentânea "são" Legba, diz $M$ aupoil. ${ }^{86}$ Exú éigualmente o intermediário entre o mundo dos vivose 0 dosdeuses. ${ }^{87}$ É por isso que "nada pode ser feito sem elee sem que oferendas Ihes sejam feitas antes de qual quer outro orixá, para neutralizar as suastendências a provocar equívocos entre os seres humanos e nas suas relações com os deuses e mesmo entre os deuses". ${ }^{88} \mathrm{D}$ e acordo com M aupoil, "é objeto de um culto original que seria arbitrário reduzir a um culto individual. Se cada indivíduo tem um Legba nele, é porque deve ser capaz de entrar em contacto em qualquer momento com afontedevidaqueéD eus". ${ }^{89} \mathrm{M}$ as, pelo contrário, deacordo com um dos seusinformantes, adivinhador, Legba reportar-se-ia a um culto individual. C adaum edificaria em casa, sob o nome de Legba, uma imagem da sua própria cólera, e procuraria amansá-la. ${ }^{90}$ Por último, Legba/Exú éo protetor dosaltares das casas, das cidades e das pessoas.

Estas características gerais conduzem os adeptos de um e outro a participarem às vezes das cerimônias celebradas para os deuses e, em certas 
regiões, quando acompanham as de Xangô, seguram na mão durante as dançasum pau grosso deforma fálica. ${ }^{11}$ Xangô, "viril e descarado, violento ejusticeiro"92 é o D eus do Trovão, um dos mais respeitados entre os orixás iorubá e nagô. É venerado sob o nome de H èviosso pelos fons do Benim.

O ra, uma curiosa coincidência, de ordem lingüística e simbólica, poderia fazer de Xangô um ator presente no caso que nos preocupa, como em muitos outros em que a bolsa era acondicionada ou utilizada por indivíduos oriundos da C osta dos Escravos. Lembramos que as orações e os desenhos da bolsa deviam permanecer embaixo de uma pedra de altar, sobre a qual várias missas deviam ser celebradas, a fim de receber um completo poder celestial. A bolsa continha igualmente uma pedra-decorisco, conhecida igualmente como pedra-deraio, outro símbolo de um poder celestial. O ra, na África, estas pedras são associadas aos cultos dos deuses do céu e, sob forma de machado de dois gumes, simbolizam $X$ angô..$^{93} O$ nde cai o raio, os seus sacerdotes procuram as pedras-de-corisco lançadas pelo orixá, consideradas como a emanação do deus e portadoras do seu axé, a sua força mística. Para manter a sua força e vitalidade, as pedras são depositadas sobre um altar, feito de um al mofariz de madeira escul pida, easpergidas com o sangue dos seus animais consagrados, o carneiro em particular. A correspondência, a equivalência simbólica entre a pedra de altar do culto católico e o sacrifício realizado sobre ela como sobre o altar consagrado à Xangô, éeera tão evidenteque podia apenas incitar a um uso mágico esincrético. Tanto maisque enquanto em portuguêsa pedra dealtar éigualmente chamada pedra de ara, na língua iorubá a pedra-de-raio de Xangô tem por nomeEdoun Ara, ara significando "corpo". ${ }^{44}$ Para terminar, quando Xangô baila, representado pelos seus adeptos, revela o seu caráter libertino e atrevido ebrandeo seu machado. $\mathrm{N}$ ão éassim muito difícil entender ou admitir a possível dupla interpretação dos símbolos en contrados neste processo.

0 olho-de-gato, outro ingrediente da bolsa, possibilitava igualmente o mesmo processo de dupla interpretação, pois a sua visão noturna pode ser considerada como um dom maléfico e sobrenatural ou aceite como uma qualidade. Assim, enquanto em numerosas culturas o animal é associado ao mal, ao diabo no 0 cidente cristão sobretudo quando é de cor preta, ele é às vezes percebido de maneira positiva na África. É-Ihe atribuído o dom de clarividência e, na África Central por exemplo, numerosas bolsas de 
curandeiros são fabricadas com a pele do gato selvagem. ${ }^{95} \mathrm{C}$ ontudo, na zona cultural deorigem de osé Francisco, o gato inscreve-seainda hojeentre os animais feiticeiros ligados à magia negra. ${ }^{96}$

Terminaremos com o exame de um dos desenhos da bolsa (Figura 1). Exame e não verdadeira análise, porque apenas serão real çados al guns elementos do grafismo, cujos significados simbólicos continuam de difícil, senão impossível, interpretação. A primeira característica diz respeito ao uso do sangue para traçar certos símbolos, uso perceptível na nítida diferença cromática - preta ou acastanhada - que parece marcar e determinar uma pertença a campos simbólicos diferentes ou mesmo opostos. Alguns elementos evocam a Paixão de C risto, com uma semelhança com as numerosas cenas da Paixão dos painéis de azulejos das igrejas portuguesas do século XVIII, mas alguns são tratados aqui de maneira mais abstrata que de costume. Juntam-se vários outros elementos, al heios à representação da Paixão, quase todos desenhados com sangue.

Assim, de cor preta, o Sol, a cruz, o seu pedestal com a caveira e os ossos, a escada, compõem um conjunto tratado classicamente, exceto a escada, à qual voltaremos mais à frente. $D$ a mesma cor, situado em baixo do montante esquerdo da cruz, o que parece ser uma ave - o Espírito Santo? - em cima de uma coluna com um traço em forma de espiral apoiada num pedestal triangular, o conjunto dando a impressão de um movimento ascendente. No topo da coluna, perto da cabeça da ave, o que parece uma pena cujo equivalente encontra-se sob o montante direito da cruz, ao pé da escada. Sobre os braços da cruz, provavel mente o martelo e os pregos apesar de não se perceber claramente o desenho na extremidade do montantedireito. N a intersecção da cruz, a coroa de espinhos, colocada ao centro deum triângulo isóscele invertido cujo topo está no ponto exato do prego que fixa os pés do C risto. D os dois lados são representados respectivamente, à esquerda, a vara com a esponja, à direita a lança que furou o flanco do crucificado. Por último, na extremidade superior da cruz, entre a haste ea Iança, a tábua com a inscrição IN RI - esta decor acastanhada- que forma a base de um triângulo, ao centro do qual inscreve-se, - no lugar da cabeça do C risto - , o que se assemel ha à coroa de espinhos, de cor preta. 
Inquisição, Pacto com O demônio e "Magia" africana em Lisboa no século XVIII • 37

FIGURA 1

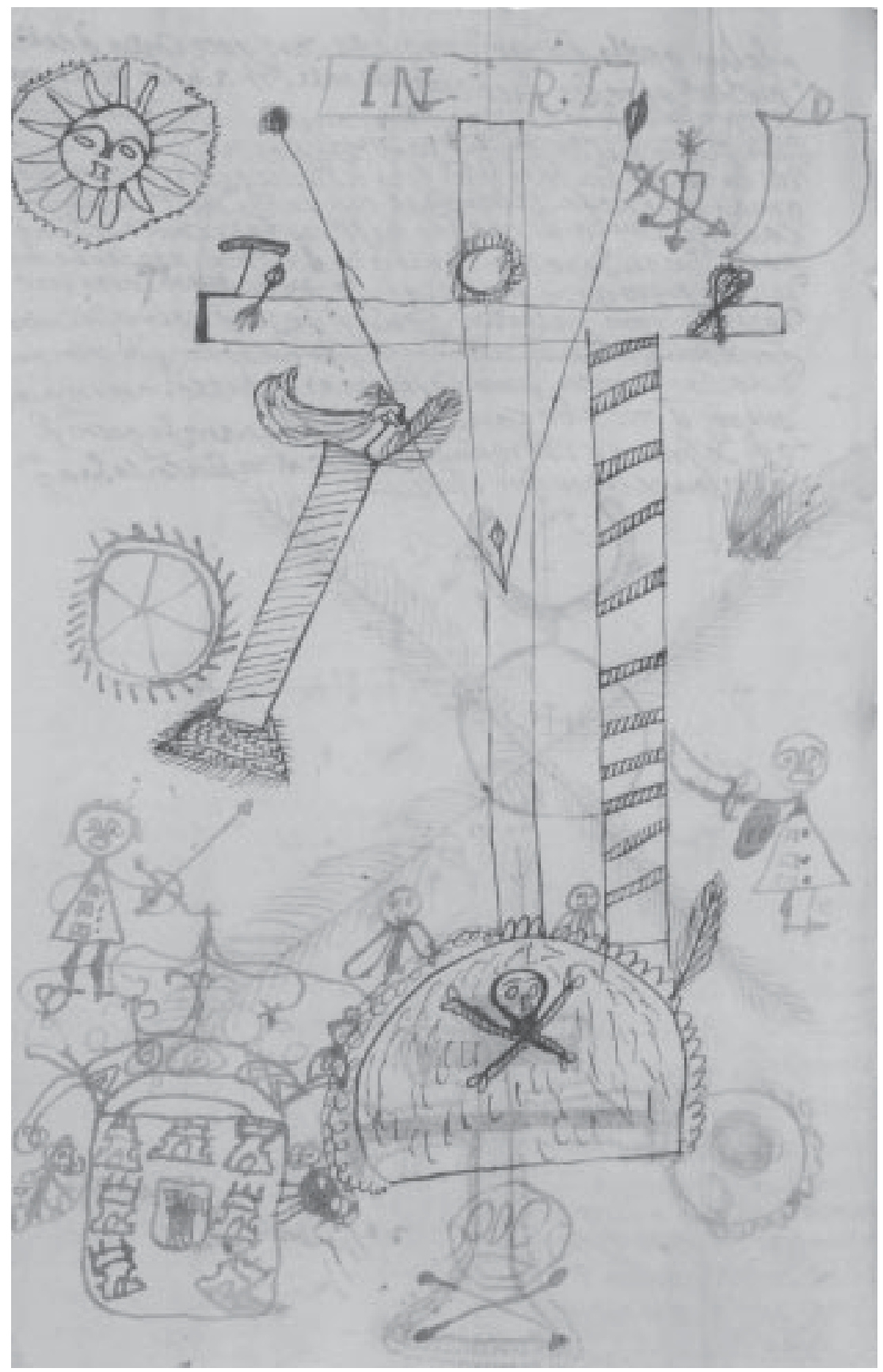


Todos os outros símbolos da folha são de cor castanha. A Lua, ou o símbolo colocado no seu lugar, oposta ao Sol, duplicada de um sinal idêntico mas menor, trespassado, por uma flecha e uma espada formando uma Cruz de S. André. Em dois outros folhetos da bolsa o mesmo símbolo é trespassado por duas flechas. Poderia por conseqüente tratar-se do selo de Salomão. D e cor castanha ainda, à esquerda e direita da cruz, dois símboIos: 0 da direita continua misterioso enquanto perto da coluna o círculo denteado, interiormente divido em cinco partes, sugere duas interpretações de resto ligadas e complementares, quer uma outra representação do Sol quer uma R oda da Fortuna assim que o deixam supor os seis raios que o dividem. D e cada lado da cruz as duas figurinhas armadas seriam a representação pouco clássica dos soldados romanos que guardavam C risto. A atitude deles sugere contudo uma situação de confrontação, uma interpretação que não pode ser recusada em razão do objetivo da bolsa e dealguns detalhes que, apesar da simplicidade dos desenhos, os diferenciam. Em primeiro lugar os rostos, dois tipos humanos contrastados, mas sobretudo 0 armamento. A figura da esquerda tem uma arma cuja guarda correspondeà dasespadasem uso na época. 0 da direita brandena mão direita um sabre largo e curto mas ligei ramente curvo e, na mão esquerda, um escudo, uma forma de proteção já abandonada pelos exércitos europeus ${ }^{97}$ mas ainda em uso na África.

Ao pé da cruz, de um lado e do outro, as duas figurinhas sobre o pedestal permanecem um enigma, embora possam representar os dois anjos que constam de numerosas iconografias da Paixão de C risto. N o entanto, aqui, ocupam o lugar geralmente reservado a outras personagens. A mesma pergunta pode ser feita sobre as duas singulares figuras parecendo insetos voadores de parte e outra da coroa portuguesa. Vem por último esta cabeça redonda que - nomeadamente em razão do desenho das orelhas não pode ser confundida com a caveira de cor preta, colocada no eixo do pedestal da cruz. Esta figura de aparência humana parece assentar como a cavei ra sobre dois ossos mas a nítida diferença das representações remete sem dúvida a um outro significado. O s arabescos da coroa provam a capacidade do autor dos desenhos de reproduzir traços mais complexos, o que nosleva a pensar queo conjunto desta composição não resulta de uma simplificação e que cada detal he tem sua importância. N o entanto é impossí- 
vel estabelecer uma estrita relação estrutural entre os símbolos. Porém, examinados separadamente, dois entreeles chamam particularmenteaatenção, e arriscaremos uma interpretação.

Em primeiro lugar, a escada, cujo desenho dos degraus - nenhum é horizontal - parece indicar um movimento em espiral. 0 ra, no que se tornou o vodu haitiano, estudado por A. M etraux, no meio do terreiro encontra-se 0 "poteau-mitan"98 enfeitado "quase sempre de bandas de cores vivas dispostas em espiral, ou borrifado de pontos claros sobre fundo uniforme". Segundo M etraux, o efeito é de ordem mais decorativa que simbólica en quanto o "poteau-mitan" representa o "caminho dosespíritos" ou, "a escada que usam para descer no peristilo quando são invocados". N o desenho do processo, este "caminho dos espíritos", se é bem daquilo que se trata, posicionado paral elamente a cruz, reforçaria, dobraria por conseguinteo poder simbólico de comunicação com as potências celestiais. M as pode igualmente se tratar de dois caminhos paralelos destinados a duas divindades, uma cristã ea outra africana. Para entrar em contacto com estas énecessário um intermediário, função queé desempenhada por Exú. 0 ra, a figura redonda colocada sob o pedestal da cruz tem, na nossa opinião, uma estranha semelhança com a representação antropomórfica de Exú descrito por viajantes no início século XVIII e como ainda hoje este érepresentado, na África e no Brasil. D e fato os três exemplos que propomos aqui (Figuras 2, 3 e 4) apresentam semelhanças com o desenho da bolsa. ${ }^{99}$ U ma outra curiosa similitude existe entre os desenhos dos outros fólios (Figura 1-a) eum dossímbolosvodu apresentado por M etraux (Figura5) ${ }^{100}$ não somente com o coração atravessado por uma espada, mastambém com 0 outro com a inscrição SI. M ilhares de quilômetros e pouco mais de dois séculos separam este desenho e os da bolsa de J osé Francisco Pedroso. 
FIGURA 1-a
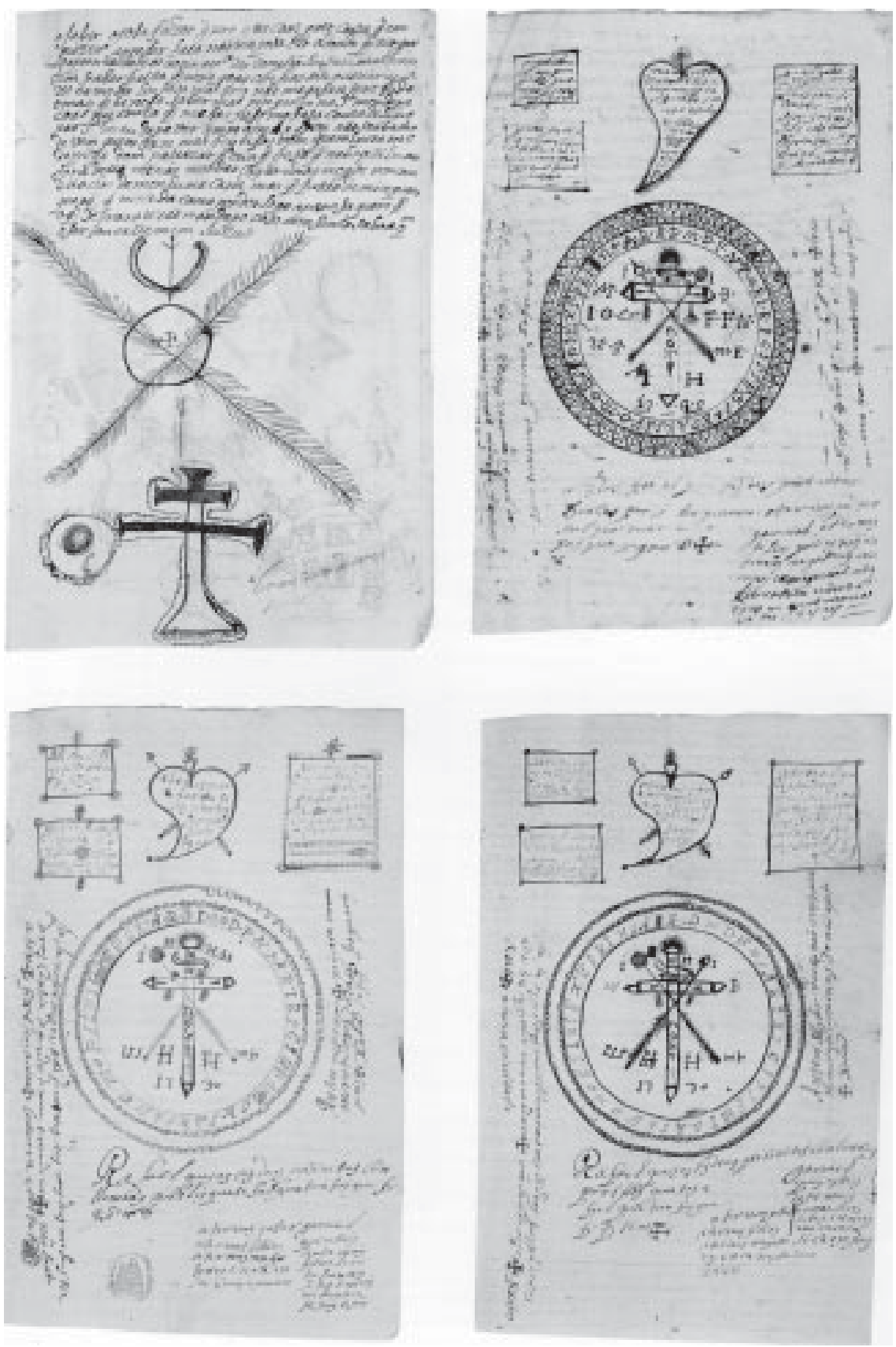
Inquisição, Pacto com o demônio e "Magia" africana em Lisboa no século XVIII 41

FIGURA 2

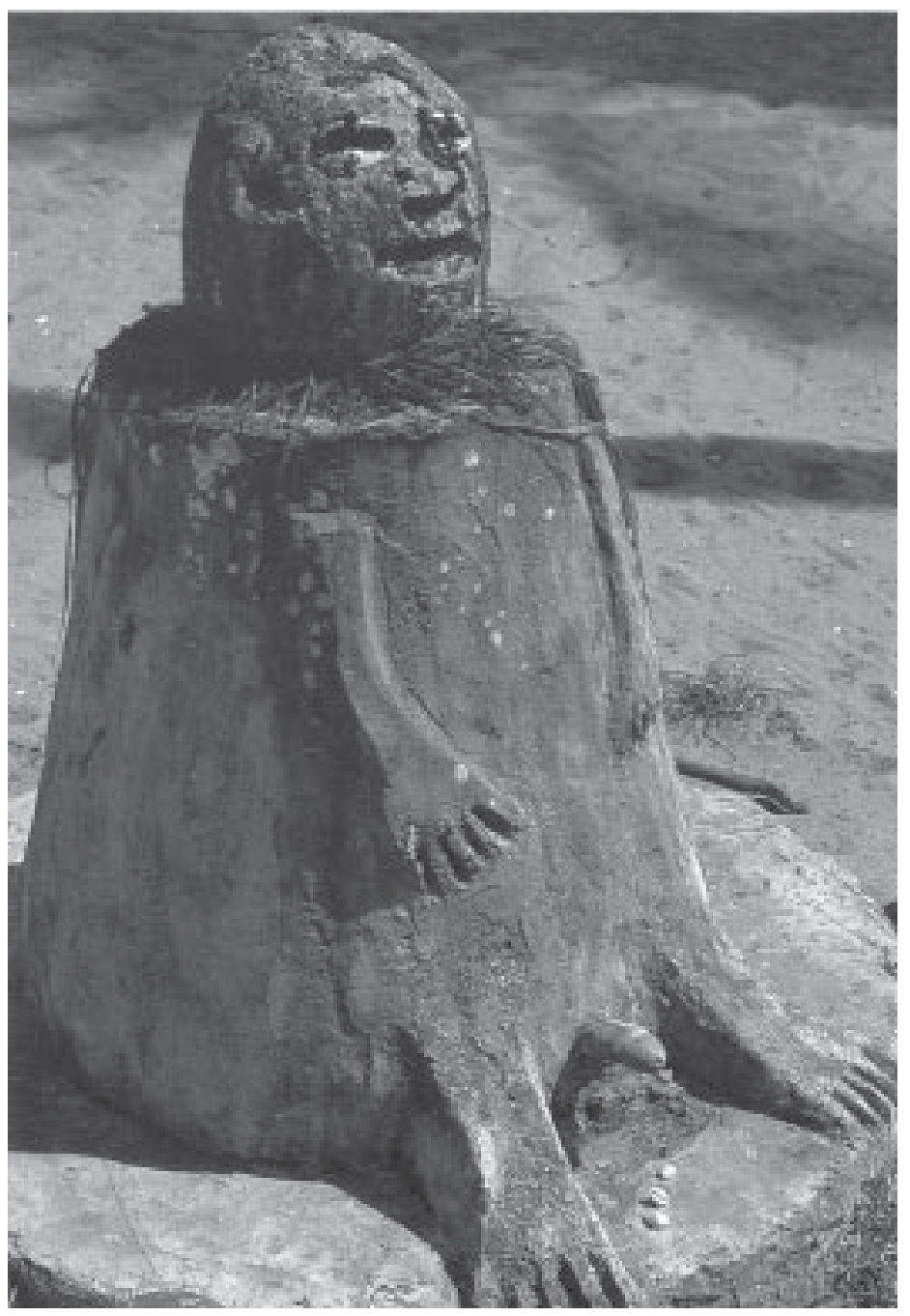


42 - Didier Lahon

FIGURA 3

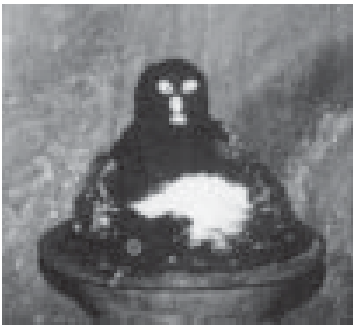

FIGURA 4

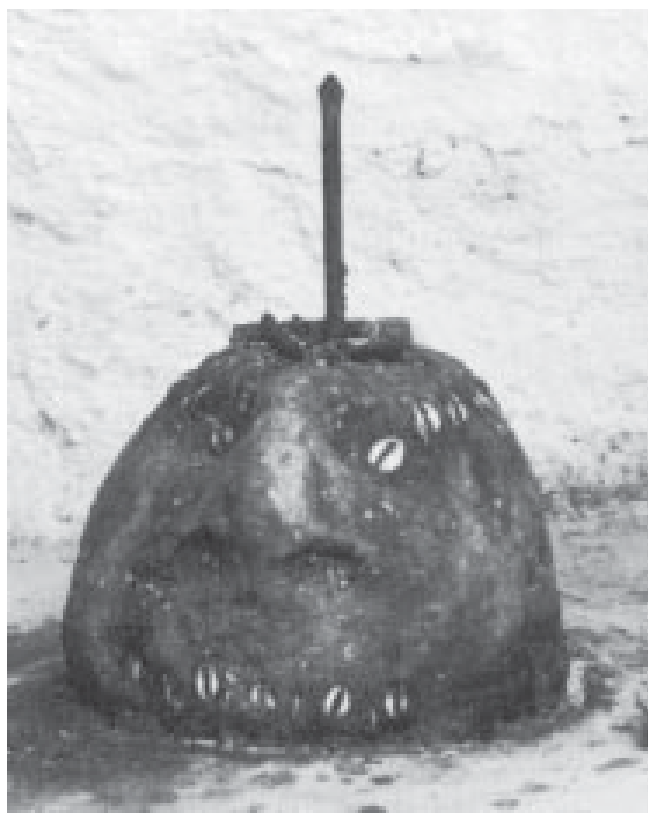


Inquisição, Pacto com o demônio e "Magia" africana em Lisboa no século XVIII 43

FIGURA 5 - Símbolo (vèvè) da deusa Ezili-freda-Daomé

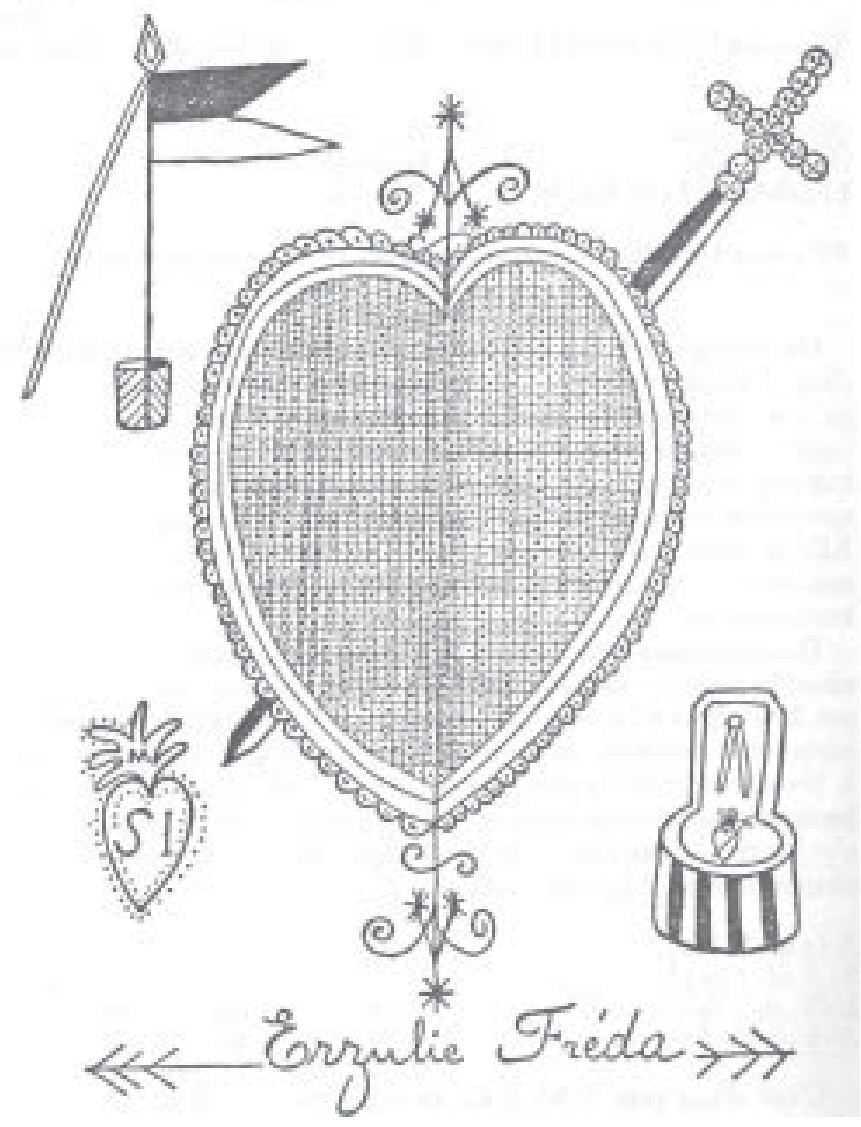


No entanto, enquanto nos campos da Cotovia José Francisco e seus companheiros praticavam rituais muitos semelhantes ao cal undu brasileiro, no $\mathrm{H}$ aiti outros escravos naturais da Costa dos Escravos juntavam-se em assembléias noturnas "sob pretexto de danças gerais". Estas, chamadas calenda, foram proibidas pelas autoridades francesas a partir de 1704 mas sem sucesso pois, em 1765, um corpo especial de tropas ligeiras foi criado para debandar estas assembléias, agora consideradas suspeitas no entender dasautoridades ${ }^{101}$ Enquanto o candomblé encontrara suas raízes no cal undu brasileiro, a calenda haitiana tranforformar-se-ia no vodu. M aupoil, sublinha a "força de expansão" dos cultos da C osta dos Escravos "e a admi ração provocada nos que a verificaram nas Antilhas, no Brasil e nos Estados meridionais da América do N orte (o D eep South), onde o tráfico de negros não conduzia apenas D aomeanos, iorubás ou M inas". 102

Em Portugal, mais que a repressão da Inquisição ou que o número relativamente fraco de população escrava importada, ${ }_{103}^{103}$ foi sobretudo a proibição precoce do tráfico em direção a Portugal, assim como o caráter principalmenteurbano da escravidão, queentravou a preservação duradoura embora oculta de certos val ores e crenças africanas.

Através de Catarina M aria, Florinda M aria, M aria de Jesus, todas angolanas, deFrancisco Antônio eseusassistentes curandeiros, naturais da Costa dos Escravos, assim como de José Francisco e seus companheiros mandingueiros, observamos como estes valores e crenças conseguiram manifestar-se, parcialmente e de maneiras mais ou menos subterrâneas, principal mente no terreno da magia. Valores e crenças já al terados, misturando-se freqüentemente, na forma e no conteúdo, às tradições populares portuguesas, sem contudo abdicarem totalmente- demodo consciente ou não - da sua memória cultural. U ma mestiçagem tornada ainda maisfácil, uma vez que a simbólica mágica presta-se naturalmente a reinterpretações além das barreiras lingüísticas e culturais. É por isso que, embora proibidas, as suas práticas nunca foram completamente secretas. Inscreviam-se numa rede de sociabilidade e de trocas complexas da qual participaram as diferentes castas de escravos e libertos mas igual mente os brancos das categorias sociais mais desfavorecidas. As fontes não permitem afirmar uma estreita cumplicidade entre esses segmentos da sociedade, mas seria errado remeter à uma absoluta marginal idade os negros envolvidos nessas práticas. 
Ao contrário, como vimos, compartilhavam, inclusive com os que os denunciaram ou acusaram, de um mesmo sistema de pen samento. $N$ a verdade, só o regime de terror estabelecido pela I nquisição levava a denunciar aquele branco ou negro com quem, durante um tempo, se tinha partilhado abertamente a mesma crença considerada heterodoxa. Sintomáticas são a denúncia de Bárbara $M$ ana e a falsa ingenuidade do moço que copiou orações deS. M arcos logo guardadas numa bolsa que conservou vários dias antes de denunciar o legítimo proprietário.

Tanto a pequena turma de forros aleijados, que mal sobrevivia graças à reputação de curandeiro de um deles, como os outros acusados, homens como mulheres, eram apenas escravos ou forros que compartilhavam as mesmas condições de vida de milhares dos seus companheiros de infortúnio. As confissões deixam aparecer as relações bastante conflituosas entre senhores e escravos e as dificuldades de sobreviver para os libertos. Porém, quando presos, desaparece a diferença entre eles e os cristãos velhos que caem nas garras da Inquisição por motivos idênticos. Para todos, magia e religião popular são dois sistemas de pensamento simbólicos que não somente não se excluem mas se completam freqüentemente, em especial quando se trata de lutar contra a doença, a desgraça, o inexplicável, quando o demônio invade o cotidiano e parece mais presente e mais acessível que $D$ eus.

\section{Curandeiros e mandingueiros negros no sistema mágico religioso português}

Para um melhor entendimento dos casos apresentados até agora torna-se necessário inseri-los no quadro mais abrangente do complexo mágico religioso português, al argando o nosso espectro das crenças religiosas em vigor entre os séculos XVI eXVIII.

$N$ a medida em que as pessoas recorrem a Francisco Antônio para tratar uma doença orgânica, mas sobretudo a manifestação de uma desgraça de origem diabólica, diagnosticada como tal tanto pelo médico como pelo exorcista, os doentes introduzem uma nova figura no campo dos práticos da eficácia simbólica: o mágico e, neste caso preciso, o curandeiro. Este, embora reconhecido pela crença ea vox populi não tinha qualquer estatuto 
legítimo, ao inverso do médico e do padre. Além disso, não sendo sempre fácil estabelecer a demarcação entre magia e religião, tampouco não aparecem de modo certo as distinções operadas pelas populações entre ritos pagãos e católicos para conjurar uma epidemia, uma seca, afastar uma invasão de gafanhotos etc. A mesma dificuldade apresenta-se entre magia e milagre quando os rituais de curas aparentam-se e quando a ação de santos $^{104}$ taumaturgos, várias vezes de âmbito local, vem juntar-se como recurso suplementar. Assim, a escolha não aparece senão como uma questão de oportunidade ou, de acordo com os indivíduos e o tipo de sua inserção social, ${ }^{105} \mathrm{com}$ a legitimidade social do prático para o qual se orientam em última instância. ${ }^{106} \mathrm{Q}$ ue este seja um negro não é sem importância e voltaremos sobre esta distinção.

\section{Da cura simbólica e do uso adequado do santo, do exorcista e do curandeiro}

Assim, no início da segunda metade do século XVIII, enquanto 0 curandeiro negro Francisco Antônio estava preso nos cárceres da Inquisição, as populações do bairro do M ocambo eparóquias circundantes tinham o privilégio, quando já não existia qualquer esperança de cura, de poder recorrer à intercessão deFr. Antônio do Lumiar, Venerável falecido em 1746 no Convento da Serra da Arrábida. Já considerado como santo quando ainda vivo, em razão dos numerosos prodígios, profecias e milagres realizados junto de pessoas de todas as condições sociais, o seu poder especializou-se de maneira característica, após a sua morte, na cura taumatúrgica. D oze anos após o seu falecimento, seu hagiógrafo e antigo confessor não Ihe atribuiu menos de 23 milagres entre os mais notáveis, al guns dos quais registrados por um notário apostólico. Exceto a nobreza, todas as categorias sociais são referidas como ben eficiárias dos seus milagres, incluindo os escravos, representados por uma mulher que sobreviveu a um parto perigoso.

A inserção desta escrava e o tipo de milagre que a ela se refere - um dos três partos da lista - não é provavelmente isento de significado e necessita de uma rápida digressão. Com efeito, a hagiografia foi publicada doisanosapósalei deproibição deentrada de novos escravos(1761) ecoloca até certo ponto a tônica sobre o valor dos escravos e o interesse da sua re- 
produção biológica. No entanto, a intercessão foi apresentada como vindo da escrava, e não da sua senhora, o que pode ser para o hagiógrafo uma maneira de significar ou afirmar a adesão das escravas à religião católica eo interesse da I greja por el as. N este sentido, a ausência deum escravo desexo masculino entreosbeneficiáriosnão étampouco sem significado. Seja como for, as duas interpretações - reprodução biológica/interesse para as mulheres negras boas católicas - podem não ser necessariamente e conscientemente relacionadas no entender do redator, sem todavia serem nem contraditórias nem incompatíveis. N ão podemos tampouco excluir uma demonstração pedagógica destinada em especial aos senhores, com o fim de mostrar-Ihes o interesse de conceder uma boa educação religiosa aos seus cativos.

Embora a Serra da Arrábida fosse para a época bastante afastada de Lisboa edeacesso particularmentedifícil, é, no entanto, na capital quemais de dois terços (17) dos milagres estão situados. Entre eles, quatro dizem respeito a moradores do $\mathrm{M}$ ocambo equatro das freguesias limítrofes onde Francisco Antônio atuava: M ercês, S. Paulo, Santa C atarina. Comparadas com as categorias sociais que comparecem no processo deFrancisco Antônio, as da hagiografia são, de modo geral, de um nível superior. ${ }^{107}$ Encontramos pessoas que têm já fé nas virtudes taumatúrgicas do Venerável e outras, sujeitos ativos ou objetos passivos do acontecimento miraculoso, a quem ela foi transmitida em situação de desespero ou de emergência. Assistimos por conseguinte a um verdadeiro processo de transmissão da de voção em relação ao Venerável e a um alargamento do seu campo social de intervenção e de influência. Todas as situações correspondem a indivíduos quer à beira da morteou gravementedoentes, quer atingidos deuma afecção perigosa, crônica ou na origem de graves incapacidades físicas, sempre confrontados com a impotência dos médicos que renunciaram e os abandonaram ao desamparo.

0 hagiógrafo, através da descrição dos comportamentos de alguns devotos, que introduziu na sua narrativa, revela um dos traços do pensamento religioso emágico da época: uma fésuperior nasforças tutelares que nos médicos e seus remédios. Assim, M anoel Ferreira D elgado, devoto fervoroso do Venerável, quando acorre para socorrer o seu vizinho que está se esvaindo em sangue pelo nariz na seqüência de uma apoplexia, começou por lançar fora todos os remédios prescritos, antes de aplicar-Ihe um 
pouco da terra da sepultura do santo homem sobre as narinas e o crânio. Apesar do sucesso temporário, em razão da pouca fé do paciente, que o conduziu atéum estado decoma gravíssimo, conseguiu restabelecer-se após a terceira intervenção do devoto, que lhe fez beber um caldo de galinha misturado com uma decocção da mesma terra.

Relíquia inesgotável, aquela terra constituía o princípio ativo simbólico da maior parte dos milagres referidos, independentemente das moléstias de resto indicadas com uma relativa precisão para a época. Assim, em Lisboa, encontramos um caso de carbúnculo maligno, de difteria - garrotilho - , três dores de dentes, um tumor no seio, doistumores ou inchações perigosas, uma febre aguda com complicações respiratórias, uma dor no peito acompanhada de diversos sintomas violentos, duas dores violentase perigosas não localizadas pelo documento e, por último, oito infecções oculares que já provocaram a cegueira parcial ou quase total de um ou dos dois olhos. Foi por exemplo o dramático caso de $\mathrm{M}$ aria de Jesus que, após ter sido sangrada dezesseis $\varsigma^{108}$ vezes sem nenhuma melhora, absorveu a água misturada com a terra da sepultura do Venerável, lavou os olhos com a mesma, e experimentou um alívio imediato. N a maioria dos casoso doente conseguia uma mel horia rápida do seu estado, às vezes a cura era quase instantânea, às vezes necessitava deal guns dias. Raramenteassistia-sea uma recaída, mas quando isto acontecia era atribuída à pouca fé do paciente, como no caso citado há pouco. N essa argumentação encontramos uma estreita similitude com o caso de Bárbara M ana, tratada por Francisco Antônio, que após ter conhecido um primeiro alívio sofreu uma recaída quase imediata quando começou a duvidar do caráter lícito da cura.

Exceto um caso, ${ }^{109}$ todas as situações apresentadas na hagiografia parecem confirmar que "o processo que conduz um paciente a voltar-se para um santo taumaturgo não constitui de modo algum uma ruptura com os cuidados anteriores, mas a última etapa quando as precedentes se revelaram vãs" ${ }^{110}$ C ontudo, não faltam os exemplos em contrário, mostrando claramente que, no pensamento religioso da época barroca, a cura dita milagrosa constituía apenas um dos meiosà disposição dos pacientes, mas que não era nem logicamente nem hierarquicamente determinada na cadeia das possibilidades curativas. Apresentar o milagre como o recurso de última instância era sem dúvida fazer obra pedagógica mas era igualmente 
esquecer a lição da I greja sobre a origem divina, por conseguinte sobrenatural, da doença, pois da mesma maneira que as epidemias ou as catástrofes naturais - que afligiam o conjunto de uma população - eram apresentadas como um aviso eum castigo celestial sancionando um desregramento social, a doença individual também era percebida como um aviso ou um castigo de D eus. Conseqüentemente, era a D eus, diretamente ou através os seus santos, que o homem devia dirigir-se em primeiro lugar para curar a sua al ma e, como reflexo desta, o seu corpo em perdição, corpo que deve se esforçar para tratar aproveitando-se de todos os meios lícitos.

Esteprincípio da primazia da cura espiritual foi analisado por José G il a propósito do uso curativo do famoso retábulo do convento dos Antonitas ${ }^{111}$ de Issenheim, na Alsácia Francesa. Aqui manifesta-se de modo paradigmático a estreita relação entrea mobilização psicológica do pacienteea curamiraculosa, graçasa uma encenação simbólica queera suficientepor si própria para provocar a cura ou favorecer o processo terapêutico.

A ordem dos Antonitas dedicava-se exclusivamente a tratar de doentes. N os seus hospitaiseram invocados vários santos. ${ }^{112} \mathrm{M}$ as, em I ssenheim, a peça soberana do arsenal curativo era o retábulo representando C risto, "composto numa intenção bem precisa (... ) : desempenhava um papel terapêutico". Este C risto "impressionante, (...) de cor esverdeada, quase em estado de putrefação, éa dor encarnada" consideraJ . Gil.. ${ }^{113} \mathrm{D}$ e acordo com 0 tto Benesch, o retábulo ficava fechado a maior parte do ano e não apresentava aos fiéis senão os painéis externos,

com ao centro, a C rucificação, sobre a vertente fixa da esquerda Santo Antônio, sobre a da direita São Sebastião. (... ) 0 retábulo fechado os reúne sob os vastos braços, semel hantes a duas asas potentes, do C rucificado. (... .) O sdoentes conduzidos ao hospital eram primeiro colocados na frente desta imagem, na esperança de um milagre; se não tivesse lugar, começava-se então 0 verdadeiro tratamento médico. ${ }^{114}$

É certo, diz J. Gil, que o propósito do autor do retábulo era propor

uma metamorfose do corpo: do corpo do Cristo e do corpo do doente. 0 milagre esperado implicaria uma forte comoção à vista do C rucificado exangue, "esfolado", tão horrível e tão próximo que provoca o empenho emocional do doente: este deveria contribuir para a cessação do sofrimento do Cristo, ao seu renascimento, à sua ressurreição. ${ }^{115}$ 
Existiria, prossegue J. Gil, um convite "à uma troca energética entre o paciente - que expulsa a sua doença, transformando-a em energia purificada que oferece ao Crucificado - e o Cristo - que faz descer sobre 0 paciente a graça do milagre".

Este "empenho emocional", que os antonitas tentavam conscientemente provocar antes de começarem qualquer cura médica, mostra que 0 milagre era bem, como o sublinha J. M. Sallmann, "uma cura terapêutica cujo uso é feito com uma relativa facilidade e cuja eficácia depende dos meios simbólicos postos em prática". N este sentido, acrescenta:

o recurso ao poder taumatúrgico de um santo situa-seno mesmo plano formal que o de outras curas de tipo "não especializada" como a medicina ou a magia, ou detipo mais "especializado" como o exorcismo. Entre estas diferentes terapêuticas, há menos concorrência que complementaridade. Os doentes recorrem apenas ao santo ou as suas relíquias em última instância, quando todas as outras formas de tratamento fal haram. $\mathrm{N}$ a ideologia comum do tempo, quase não há hierarquia entre elas, e o fato de solicitar os recursos da medicina, da magia ou da santidade continua a ser apenas uma questão de circunstância. A inspiração do momento prevalece sempre, sobretudo quando há urgência. ${ }^{116}$

O ra, esta urgência, se evidentementetem a ver em primeiro lugar com o estado do doente, pode igualmente resultar de um malogro dos médicos, exorcistas ou mesmo da cura miraculosa. D ito de outra maneira, nenhum dos operadores culturais, encarregados de "fazer compreender ao paciente que a sua perturbação é provocada por uma ruptura das suas relações com o sagrado e que só ele pode restabelecêlas", ${ }^{117}$ conseguiu mobilizar o seu potencial emocional quelhepermite superar o mal. Para o doente isso significava igualmente que todos os modelos lícitos de intervenção simbólica falharam. Porém, ainda permanecia a vasta gama dos recursose esperanças oferecidos pela magia. D e fato, apesar de terem sido considerados definitivamente fora da lei e assimilados à esfera diabólica desde as O rdenaçõesM anuelinas, ${ }^{118}$ os práticos da cura terapêutica, os curadores ou, de acordo com as suas denominações regionais, saludadores, benzedores, mezinhei ros efeiticeiros continuaram a recrutar em todos os meios da sociedade, inclusive entre os eclesiásticos, os médicos e a aristocracia. ${ }^{119} \mathrm{~J}$. 
Pedro Paiva cita o caso de um familiar e médico do Santo 0 fício que acabou por se denunciar por se ter

curado com pessoas supersticiozas efeiticeiras, esperando dellasenganosamente o remedio para meusachaques, pois o não achava em nenhuma outra parte; ao que me obrigou 0 amor da vida com receio da morte. ${ }^{120}$

0 maisinteressante da sua confissão équetudo permite acreditar que ele foi curado. D efato não se pode duvidar que entre as mãos dos práticos da magiailícitaa eficácia simbólica, transcendendo as barreiras erigidas pela lei e religião, surtia resultados, onde os médicos e os exercícios espirituais não tinham obtido êxito. ${ }^{121} O$ doente cura-se, afirmaLevi-Strauss, analisando a eficácia da curaxamanistanumacultura alheiaànossa. Cura-seprovocando "un déblocage du processus physiologique, c'est-à-dire la réorganisation, dansun sensfavorable, dela séquencedont [le] malade subit ledéroulement". Por isso,

la curechamaniquese placeàmoitiéchemin entrenotremédecineorganique et desthérapeutiques psychologiquescommelapsychanalyse. Son originalité provient de ce qu'elle applique à un trouble organique une méthode très voisine de cette dernière. ${ }^{122}$

Todavia, como o estabeleceu claramente Levi-Strauss:

l'efficacité de la magie implique la croyance en la magie, et que celle ci se présente sous trois aspects complémentaires: il y a d'abord, la croyance du sorcier dansl'efficacitédesestechniques: ensuite, celledu maladequ'il soigne ou dela victimequ'il persécute, dans le pouvoir du sorcier lui-même; enfin, la confiance et les exigences de l'opinion collective, qui forment à chaque instant une sorte de champ de gravitation au sein duquel se définissent et se situent les relations entre le sorcier et ceux qu'il ensorcelle. Aucune des trois partiesen causen'est évidemmentà mêmedeformer unereprésentation claire del'activitédu sympathique, et destroubles (...) appelés homéostatiques. ${ }^{123}$

Essa necessária partilha das crenças entre os diferentes atores duma cura, da qual dependea eficácia simbólica no plano psicológico efisiológico, vigora não somente para o feiticeiro, para o xamã, como para o exorcista, o santo, e o médico, tanto para uma cura bem sucedida como para casos de malogro. Porque, seguindo esta lógica, pode-se pôr em paralelo os efei- 
tos de todos os tipos de previsões negativas proferidas por qualquer um deles. ${ }^{124}$ A esse respeito, J. M . Sallmann considera o estatuto do santo como "intermediário entre o do psicanalista e o do xamã". Como este,

age sobre a personalidade social do paciente, ajudando-o a situar-se de novo no seu quadro de referência cultural, essencial mente pela adesão sem rodeio à Fé católica e a crença ao culto dos santos. Para conter um conflito de origem psíquica (a possessão diabólica por exemplo), elabora novas defesas culturais (o exorcismo), e para curar uma doença orgânica, atua sobreo sistema simpático do pacientee as componentes psicossomáticas da doença. ${ }^{125}$

Por essa razão nos questionamos sobre o lugar ea função do feiticeiro negro, curandeiro ou mandingueiro, quando a sua prática se inscreve no seio de um sistema simbólico mágico-religioso a priori al heio ao seu. Recordemos que os doentes declaram ter consultado Francisco Antônio após uma sucessão de fracassos, tanto da parte do médico como, freqüentemente, do exorcista, que confessaram sua inaptidão e diagnosticaram um ataque sobrenatural, diabólico, superior aos seus poderes. Tal atitude pode parecer paradoxal. C ontudo ela revela que, durante séculos, as sutilezas teológicas introduzidas pela contra-reforma tiveram apenas um fraco resultado, enquanto o uso eabuso da onipresença eda onipotência do diabo por parte do corpo eclesiástico podiam apenas produzir o efeito perverso que se conhece: estabelecê-lo quase à igualdade de poder com D eus. Q uando os agentes legítimos confessavam ter sido vencidos pelo $M$ aligno e aconseIhavam procurar socorros "noutro lugar", quer dizer, quando todososmeios lícitostinham falhado, tentar desviar a influência nefasta do demônio constituía uma saída lógica e satisfatória, dado que sem mesmo ter que recorrer ao imaginário pacto com o demônio, podia ser alcançada graças a intermediação dum curandeiro. N este instante entravam em cena todas as redes de conhecimentos que conduziam o infeliz à porta do "feiticeiro" ao seu alcance, ou do prático com a melhor fama. 0 que explica a existência de certos indivíduos especializados, os inculcadores, encarregados de dirigir as pessoas para o mágico de melhor reputação e qualidade que correspondesse às suas necessidades. Alguns destes intermediários assumiam a função de fiador "da capacidade de certos agentes e eram mesmo muitas vezes os únicos meios de acesso a certas pessoas". Representavam uma espécie de garantia contra os charlatães. ${ }^{126}$ 


\section{Diabo familiar contra Diabo do Outro}

D e acordo com J. P. Paiva, o número dos curandeiros era tão importante em Portugal que não existia uma freguesia, por pequena que fosse, que não tivesse o seu. A sua área de ação era habitual mentelimitada a esta, exceto quando a sua fama extravasava os limites geográficos iniciais. ${ }^{127}$

Porque um branco se voltaria para um feiticeiro negro quando existiam tantos feiticeiros brancos em Lisboa? Q uais crenças mágico-religiosas eram compartilhadas, quais representações comuns do sobrenatural, onde e como inscrevia-se $F$. Antônio no seio desta cadeia complexa de agentes do sagrado?Também, não écerto quea notoriedadede Francisco Antônio fora da sua paróquia assentava essencialmente sobre os seus resultados. Se, como hoje é ainda o costume, os doentes identificaram o responsável da sua desgraça entre os seus parentes, familiares ou vizinhos, numerosos brancos que recorriam aos seus serviços procuravam o socorro de um prático estrangeiro à sua comunidade. Inscrevia-se pois numa continuidade, onde o seu caráter "exótico" Ihe conferia um suplemento de eficácia; esperava-se dele "uma força desconhecida edesconcertante". ${ }^{128}$ Estrangeiro, Francisco Antônio 0 era, social, territorial e culturalmente. D e qualquer modo, era assim que devia ser considerado, pois, ontem como hoje, não se consulta um "feiticeiro" ou "curandeiro" negro da mesma maneira que um branco. D esdea al ta antigüidade, os escravos, os dominados demaneira geral, sempre foram vistos como detentores de uma magia superior à dos dominantes. ${ }^{129} \mathrm{O}$ ra, 0 essencial do poder atribuído a Francisco Antônio firmase sobre o seu estatuto de estrangeiro e principalmente de representante de povos cuja humanidade cultura são negadas, povos qual ificados de selvagens ou bárbaros, entregues ao paganismo, a costumes ecrenças inspiradas pelo $D$ iabo, representados de maneiras mais fantasmagóricas que reais. Batizados, Iadinizados, ${ }^{130}$ continuavam a não ser considerados senão como "novos convertidos", sempre suspeitos de conservar genuinamente laços privilegiados com as forças diabólicas que tinham antes do batismo. ${ }^{131} \mathrm{As}$ sim, no caso de Francisco Antônio, era perto do representante de uma cultura considerada possuidora de poderes mágicos diferentes, quando não superiores, queas pessoas procuravam proteção ou ajuda. N essa perspectiva, eleteriatido uma maior habilidade para lutar contra asforças obscuras, 
das quais ele mesmo era procedente, que um branco que não conhecia, ou tinha esquecido, todos os enganos delas.

Seja como for, se Francisco Antônio, ou o que ele representava, não compartilhasse necessariamente com os seus doentes brancosa noção cristã ocidental do $\mathrm{D}$ iabo e do $\mathrm{M}$ al, todos compartilhavam a mesma convicção de que a desgraça ea doença tinham origens sobrenaturais e que a estas era necessário dirigir-se, quer para conciliá-las, quer para combatêlas. U ma base comum suficiente para favorecer um processo sincrético e para que funcionasse a eficácia si mbólica do ritual, salvo quando o paciente assustava-se em razão da sua aproximação a um demônio que não Ihe é familiar. Foi provavelmente o que aconteceu a Bárbara M ana, paciente e responsável pela infelicidade de Francisco Antônio. M as quantos outros pacientes brancos foram consultá-lo e ficaram satisfeitos depois de terem consultado sem sucesso outros curandeiros brancos? Teriam sido Francisco Antônio e os outros curandeiros negros da capital o último recurso no conjunto das curas ilegítimas?

A esse respeito, nesta busca de poderes mágicos diferenciais e cumulativos, seria interessante conhecer o papel que desempenhavam os diferentes grupos estrangeiros marginais e dependentes da sociedadeportuguesa, bem como as relações quemantinham entresi. V ários processos deixam antever contactos estreitos entre negros, mulatos e mouriscos. N o campo da cura ou da feitiçaria maléfica, cada casta poderia ter desempenhado, em relação às outras, um papel complementar, análogo ao descrito por $\mathrm{C}$. Bernand para a América H ispânica, hoje ainda em vigor. ${ }^{132}$ Por último, como vimos com as bolsas de mandinga e as curas de Francisco Antônio, é necessário recordar que para um indivíduo a coexistência entre dois sistemas de pensamento ou de valores é possível quando não se confrontam. É por essa razão que quem usava uma bolsa devia abandoná-la temporariamente quando desejava entrar numa igreja para cumprir os seus deveres de cristão. N estesentido, osacusados, brancos ou negros, não mentiam quando juravam nunca ter renegado $D$ eus. $N$ ão revelaria essa ausência de confrontação e contradição do foro íntimo uma das formas mais elaboradas da mestiçagem cultural? A Inquisição não podia evidentemente admitir nem compreender esta concepção, provavelmente compartilhada por um grande número de naturais do reino, assim como por escravos e forros. $M$ as, 
sem dúvida, estes homens e mulheres, apesar de manifestarem a aceitação pelo menos parcial deum novo imaginário, não renunciaram a manter um "pensamento oferto" a alguns deuses do panteão africano, pensamento para sempre ignorado pelo tribunal da Inquisição e pelos tribunais eclesiásticos.

\section{Bibliografia}

AU GÉ, M arc. Le Géniedu paganisme. Paris: Gallimard, 1982. . Le dieu objet. Paris: Flammarion, 1988.

BARO J A, Julio C aro. Les sorcières et leur monde. Paris: G allimard, 1972.

BEN ESCH , 0 tto. La peintureallemande, deD ürer à H olbein. G enève: Skira, 1966.

BEN IST E, José. Ò run Àiyé, o encontro dedoismundos, 0 sistema derelacionamento nagô-yorubá entre o céu ea terra. Rio de Janeiro: Bertrand-Brasil, 1997.

BERN AN D , C. N egrosecclavosylibresen lasciudadesamericanas. CD -rom Colección Proyectos H istóricos Tavera (I) DIG IBIS: M adrid, 2000.

BET HEN COU RT, Francisco. 0 imaginário da magia, féticeiras, saludadorese ni gromantes no séc. XVI. Lisboa: U niversidade A berta, 1987.

BO URDIEU, P. Une interprétation dela théorie dela religion selon $M$ ax Weber. In: Archives Européennes de Sociologie, XII, 1, 1971.

CALAIN H O, D aniela Buono. M etrópole das mandingas. Religiosidade negra e inqui s ção portuguesa no antigo regime. Tese de doutoramento. N iterói, 2000.

26-26 (2001).

. Jambacousseegangazambes: feiticeiros negros em Portugal. Afro-Ásia,

. N egros hereges, agentes do diabo. Religiosidade negra e inquisição em Portugal - séculos XVI-XVIII. In: FLO RENTIN O, M anolo \& MACH AD O, Cacilda (O rgs.). Ensaios sobre a escravidão (I). M inas G erais: U FM G, 2003.

CAPO N E, Stefania. La quête de l'Afrique dans le candomblé, pouvoir et tradition au Brésil. Paris: Karthala, 1999.

CHEVALIER J. \& GHEERBRANT A. Dicionário dos símbolos, Lisboa: Ed. Teorema, 1994.

DESCH OBI, T. J. Combat and thecrossing of thekalunga. In: HEYWO O D, Linda M. Central Africans and cultural transformation in the american diaspora. C ambridge: Cambridge University Press, 2001. 
DURKH EIM , E. Les formes élémentaires de la vie religieuse. Paris: PU F., 1968. FO N SECA, Jorge. Escravos no sul de Portugal. Séculos XVI-XVII . Lisboa: Ed. Vulgata, 2002.

FO U CAU LT, M ichel. H istória da sexualidade I: a vontade de saber. Paris: Gallimard, 1976; Lisboa: Relógio D ’Água Editores, 1994.

FRAG IN ALS, M anuel M oreno. A portes culturalesy deculturación. In: La H istoria como arma y otros estudios sobre esclavos, ingenios e plantaciones. Barcelona, 1983. GIL, José. Les métamorphoses du corps. Paris: La D ifférence, s.d.

GIN ZBURG, Carlo. Les batailles nocturnes. Paris: Flammarion, 1984.

G lossário de magia e esoterismo. São Paulo: N ETRA, 2001.

ISERT, Paul Erdman. Voyages en guinée et dans lesîles caraïbes en amérique. Paris: Karthala, 1989.

KARASCH , M ary C. A vida dosescravosno Rio de Janeiro, 1808-1850. São PauIo: Companhia das Letras, 2000.

LAH O N , Didier; N ETO , M aria C ristina \& et al. C atálogo da exposição 0 sne gros em Portugal - Sécs. XV a XIX. M osteiro dos Jerónimos de Belém, Lisboa, 239-1999/24-1-2000, Lisboa: C.N.C.D.P., 1999.

LAH O N, Didier. Violência do estado, violência privada. 0 verbo e o gesto no caso Português. In: FLO REN TIN O, M anolo \& M ACH AD O , C acilda. Ensai os sobre a escravidão (I). M inas G erais: UFM G, 2003.

Ledictionnairedesinquisiteurs. Valence, 1494. Revisitado por Louis Sala-M olins, Ed. Galilée, 1981.

LEBRU N , F. M édecins, saintset sorciersaux 17eet 18esièdes. Paris: M essidor, 1983. M AN D RO U X, R. M agistratset sorciersen Franceau XVII e siècle. Paris: Seuil, 1980. M anuel desinquisiteurs d'Eymerich. Paris: M outon-EH SS, 1973.

M AU PO IL, Bernard. La G éomancie à I'ancienne côte des esclaves. Paris: Institut d'Ethnologie, 3a ed., 1998.

M AUSS, M. Sociologie et Anthropologie. Paris: PUF, 1980.

METRAUX, A. Levaudou haitien. Paris: Gallimard, 1958.

M OTT, Luís. Etnodemonologia: a vida sexual do D iabo no mundo íbero-americano. In: Religião e Soci edade, n.122, 1985.

M U CH EM BLED , R. Sorcières, justice et société aux 16 e et 17e siècles. Rio de Janeiro: Imago, 1987. 
. La sorcière au village, XV-XVIII siède. Folio: Gallimard, 1991.

PAIVA, J. P. Bruxaria esuperstição num pais "sem caça às bruxas", 1600-1774. Lisboa: N otícias editorial, 1997.

- Práticas e cren ças mágicas, o medo ea necessidade dos mágic cos na diocese de Coimbra (1650-1740). Coimbra: M inerva, 1992.

LO UREIRO, Rui M . \& GRUZIN SKI, Serge(C oord.). Passar asfronteiras- Actas do II Colóquio Internacional sobre M ediadoresCulturais- SéculosXV a XVIII. Lagos: Centro de Estudos Gil Eanes, 1999.

SALLM AN N , Jean-M ichel. N aples et ses saints á l'âge baroque (1540-1750). Paris: PUF, 1994.

SAN TAN A, Francisco. Bruxase curandei rosna Lisboa Joanina. Lisboa: Academia Portuguesa da H istória, 1996.

SANTO S, M aria H elena C arvalho dos. A abolição da inquis ção em Portugal- um acto de poder. Inquisição. In: Actas do 10 congresso luso-brasileiro sobre inquisição, Lisboa, 1987. Lisboa: Universitária Editora, 1989, v. III.

SCHUTZEN BERGER, Anne Ancelin. Forme européenne inconsciente du chamanisme: la réalisation automatique des prédictions.Transe, chamanisme, possession, Actesdes I I rencontresInternationalesdeN ice. Avril: 1985, N ice: Editions Serre, 1986.

SLEN ES, Robert W. M alungu, N goma vem! África encoberta edescoberta no Brasil. Luanda:M useu N acional da Escravatura, IN PC, 1995.

. The great porpoise-skullstrike: central african water spirits and slave identity in early-nineteenth-century Rio deJane ro. In: H EYW O O D, LindaM . (ed.). Central africansand cultural transformation in the american diaspora. Cambridge: Cambridge University Press, 2001.

SI LVA, M . B. N izza da. Culinária colonial. 0 ceanos, n. 42, C.N.C.D.P., abril/ junho 2000. Lisboa: C.N.C.D.P.

SO UZA, Laura de M ello e. Inferno atlântico. demonol ogia e colonização. séculos XVI-XVIII. São Paulo: Companhia das Letras, 1993.

. Curasmágicasy sexualidad en el siglo XVIII luso-brasileño. In: Q UEIJA, BertaAres\& G RUZIN SKI, Serge (C oord.). Entredosmundos- frontei rasculturales y agentes mediadores. Sevilla: E.E.H .A, 1997, pp. 441-450.

. 0 diabo ea terra de santa cruz, fe tiç̧aria ereligiosidadepopular no Brasil. São Paulo: Companhia das Letras, 1986. 
ST ELLA, Alessandro. H istoiresd'esclavesdansla péninsuleibérique. Paris: EH ESS, 2000.

WALKER, T imothy D ale. D octors, folk medecineand theinquisition: therepression of popular healingin Portugal during theenlightenment era. Tese de doutoramento. Boston University, 2001.

THIERS, Jean Baptiste. Traité des superstitions. Paris: Le Sycomore, 1984.

VASCO N CELO S, José Leite de. Signum Salomonisa figa - a barba em Portugal. Lisboa: Publicações D om Q uixote, 1996.

VERGER, P. Fatumbi, Les dieux yoruba en afrique et au nouveau monde. Paris: M étailié, 1982.

\section{Notas}

${ }^{1}$ BECKFO RD , W. Diário deWilliam Beckford em Portugal eE spanha. Lisboa: BN , 1988, p. 50.

2 SANTOS, M aria Helena Carvalho dos. A abolição da Inquisição em Portugal - Um acto de Poder. Inquisição. Actas do 1ํㅡ Congresso Luso-Brasileiro sobre Inquisição, Lisboa, 1987. Lisboa: Universitária Editora, 1989, v. III, p. 1382.

3 "a importância primordial deste facto que marca as atitudes religiosas medievais e modernas no nosso país: o cristianismo afirma-se contra o maometanismo e contra o judaísmo, não se destriçando, no primeiro caso, o confronto religioso do confronto militar, político, social ecultural (... )" - BET H EN C O U RT, Francisco. 0 imaginário da magia, fétice ras, saludadorese nigromantes no séc. XVI. Lisboa: U niversidade Aberta, 1987, p. 246

${ }^{4}$ I AN T T, Inq. Lisboa, Processo-D enuncia, no 14.105, 1 fl. (1796).

5 PAIVA, José Pedro. Bruxaria e superstição num país "sem caça às bruxas", 1600-1774. Lisboa: N otícias editorial, 1997, p. 150

6 "O ra, a confissão éum ritual de discurso em que o sujeito quefal a coincidecom o sujeito do enunciado; é igualmente um ritual que se desdobra numa relação de poder, porque não se confessa sem a presença, pelo menos virtual, de um parceiro, que não é simplesmente 0 interlocutor, mas a instância que requer a confissão, a impõe, a aprecia e intervém para julgar, punir, perdoar, consolar, reconciliar; um ritual em que a verdade se autentifica pelo obstáculo epelas resistências queteve de vencer para se formular; por fim, um ritual em que a simples enunciação, independentemente das suas consequências externas, produz, em quem a articula, modificações intrínsecas: ela inocenta-0, redime 0 purifica-0, descarrega-o das suas faltas, liberta-0, promete-lhe a sal vação." FO U C AU LT, M ichel. H istória da sexualidade I: a vontade de saber. Paris: Gallimard, 1976 / Lisboa: Relógio D 'Água Editores, 1994, p. 66.

7 PAIVA, J.P., op. cit., p. 356. 
${ }^{8}$ G racia Luzia IANTT, Inq. Lisboa, o 433 (1736); Antónia da Cruz, Inq. Lisboa, № 11.177 (1745).

${ }^{9}$ Francisco J oséPedroso, natural daC osta daM ina; IAN T T, Inq. Lisboa, no 11.774 (1731). D etentor de uma bolsa de mandinga, ele afirma que sempre pensou que ela não tinha sido feita com a ajuda do demônio, "que era coisa de D eos", ao contrário de uma outra, cuja existência conhecia mas que se recusava a usar.

${ }^{10}$ IAN TT, Inq. Lisboa, Processo no 6.286, (1733).

${ }^{11}$ PAIVA, J. P., op. cit., p. 129. Sobrea violência dos senhores: LAH O N , D idier. Violência do Estado, violência privada. 0 verbo eo gesto no caso português. In: FLO REN TIN O, M anolo \& M ACH AD O Cacilda (O rgs.). Ensaios sobre a Escravidão (I). Ed. U G M G, 2003, pp. 87-120.

${ }^{12}$ FRAGIN ALS, M anuel M oreno. Aportes culturales y deculturación. La H istoria como arma y otros estudios sobre esclavos, ingenios e plantaciones. Barcelona, 1983, pp. 29-31, citado por SLEN ES, Robert W. M alungu, N goma vem! África encoberta e descoberta no Brasil. Luanda: M useu N acional da Escravatura, IN PC, 1995, 24 p. 15.

${ }^{13}$ IAN T T, Inq. Lisboa, Processosno 437, Florinda M ariadeSão José, (1736); SAN TAN A, Francisco. Bruxasecurandeirosna Li sboa Joanina. Lisboa: Academia Portuguesa da H istória, 1996, pp.125-126.

14"e seu Pay se chamava Catumbeque e sua M ai M áve(...) Q ue ella tinha (... ) duas irmaõs humachamada Q uiloma eoutrachamadaC apaco eoutraquemorreo não Ihelembrao nome" ${ }^{15}$ FRAN ÇOIS, M edeiros. L'O ccident et I'Afrique(XIII eXVesiècle). Paris: Karthala-C.R.A, 1985.

${ }^{16}$ SLEN ES, Robert W., op. cit., p. 10 eT heG reat PorpoiseSkullStrike Central african water spirits and save identity in early-nineteenth-century Rio de Janeiro. In: H EYW O O D, Linda M. (ed.). Central africans and cultural transformation in the American diaspora. Cambridge: CambridgeU niversity Press, 2001, pp. 183-208 e, na mesma obra; D ESCH $\mathrm{O} B \mathrm{~B}, \mathrm{~T}$. J. Combat and the crossing of the Kalunga. pp. 353-370.

${ }^{17}$ KARASCH , M ary C. A vida dos escravos no Rio de Janeiro, 1808-1850. São Paulo: Companhia das Letras, 2000, pp. 418-419. Para Portugal; FO N SECA, Jorge. Escravosno sul dePortugal. SéculosXVI-XVII. Ed. Vulgata, 2002, pp. 237-238; AL M AD A, AndréÁlvares d'. Tratato Breve dos Rios de Guiné do Cabo Verde, (1594). In: M onumenta M issionaria Africana, 2a Série, v. III, doc. 92, p. 339.

${ }^{18}$ IAN TT, Inq. Lisboa, Processo 348, Joana Antónia (1746).

${ }^{19}$ IAN TT, Inq. Lisboa, Processo 2.279, M aria de Jesus (1735).

${ }^{20}$ SO UZA, Laura de M ello e. Inferno atlântico. D emonologia e colonização. Séculos XVIXVIII. São Paulo: Companhia das Letras, 1993, p. 170.

${ }^{21}$ Idem, 172.

22 WALKER, Timothy Dale. D octors, folk medecine and the Inquisition: the repression of popular healing in Portugal during the enlightenment era. Tese de doutoramento. Boston University, 2001. 
${ }^{23}$ CH EVALIER J. \& GH EERBRANT, A. D icionário dosśmbolos. Lisboa: Teorema, 1994, p. 149. No entanto o Levitico $(9,4)$ considerava-o como um animal impuro.

${ }^{24} \mathrm{~N}$ ão encontramos qualquer referência ao transporte por via aquática nas obras seguintes: Le D ictionnaire des inquisiteurs. Valence, 1494, "revisitado" por Louis Sala-M olins, Ed. Galilée, 1981; LeM arteau dessorcières G renoble: Ed. J. M illon, 1990, C ap. III; M anuel desInquisiteurs d'Eymerich. Paris: M outon-EH SS, 1973; M AN D RO U X, R. M agistratset sorciers en France au XVII e siècle. Seuil: 1980; M U CH EM BLED, R. Sorcières, justice et société aux 16e et 17e sièdes. I mago, 1987; Idem, La Sorcière au village, XV-XVIII e siède. G allimard: Folio, 1991; CARO , Baroja, Julio. LesSorcièreset leur monde. G allimard, 1972; ESC AM ILLA-C O LIN , M . Crimes et châtiments dans I'Espagne I nqui sitoriale. T. 2, Berg International, 1992; G IN ZBU RG , C arlo. LesBataillesnocturnes. Paris: Flammarion, 1984. 25 PAIVA, J. P., op. cit., pp.41e 47.

${ }^{26}$ BET H EN C O U RT, F., op. cit.; PAIVA, J. P. Práticas e crenças mágicas, o medo ea necessidade dos mágicos na D iocese de Coimbra (1650-1740). Coimbra: M inerva, 1992 eidem, pp. 208-209.

${ }^{27}$ 1761: proibição de importação de novos escravos na metrópole. 1773: Lei do ventre livre e libertação dos escravos de quarta geração.

28 "D ois alvarás, um de 1756 e 0 outro de 1788, permitiam aos oficiais, mestres, marinheiros e mais homens do mar que navegassem para o Brasil dedicar-se por sua conta e risco a um pequeno comércio al imentar" de produtos da metrópole. SI LVA, M . B. N izza da. Culinária colonial. 0 ceanos, C.N.C.D.P., no 42, abril/junho 2000, p. 27.

29 SO U ZA, Laura de M ello e. Curasmágicasy sexualidad en el siglo XVIII Luso-Brasileño. In: QU EIJA, Berta Ares \& GRUZIN SKI, Serge (O rgs.). Entre dos mundos - Fronteiras culturalesy agentes mediadores Servilla: E.E.H .A, 1997, pp. 441-450. N esteartigo ela trata, entre outros, do caso de D omingos Alvares (IAN T T, Inq. Évora, no 7.759), negro natural da Costa da M ina, batizado no Brasil, curandeiro e saludador, sentenciado em 1742 e degredado na cidade de $C$ astro-M arim, fronteiriça a Espanha, no extremo sul do país. $\mathrm{N}$ ovamente preso em 1747 por ter reincidido na mesma culpa, associando a esta o mito tipicamente ibérico da busca de tesouros e do desencanto de mouras, foi desterrado em 1749 para Braga, no extremo N orte do país. As suas práticas correspondem às descritas para o sécul o XVI por BET H EN C O U RT, F., op. cit., p. 53. Sobre o tema dos M ediadores Culturais ver LO U REIRO, Rui M \& \& GRU ZIN SKI, Serge (O rgs.). Passar as fronteiras, Actas do II Colóquio Internacional sobreM ediadoresCulturais- SéculosXV àXVIII. Lagos: Centro de Estudos Gil Eanes, 1999.

30 "Sans doute, sans les dieux, les hommes ne pourraient vivre. M ais, d'un autre coté, les dieux mourraient si le culte ne leur était pas rendu. C elui-ci n'a donc pas uniquement pour objet defairecommunier les sujets profanes avec les êtres sacrés, mais aussi d'entretenir ces derniers en vie, de les refaire et de les régénérer perpétuellement.(... ) La raison d'être des cultes, [...], ne doit pas être recherchée dans les gestes qu'ils prescrivent, mais dans le renouvellement intérieur et moral queces gestes contribuent à déterminer. C equelefidèle donne réellement à son dieu, cenesont pas les aliments qu'il dépose sur l'autel, ni le sang 
qu'il fait couler de sesveines: c'est sa pensée"'. D U RKEIM , E. Lesformesélémentai resdela viereligi euse. Paris: PU F, 1968, pp. 494-495. Livro III, cap. II: 0 culto positivo, parteV, no parágrafo começando com: "Il faut donc se garder de croire avec Smith..."

${ }^{31}$ IAN T T, Inq. Lisboa, Processo no 11.179 (1744). Francisco Antônio, preto forro, natural da Costa da Mina.

32 "Sont aussi destinés à être magiciens certains personnages que signalent à l'attention, à la crainte et à la malveillance publique, des particularités physiques ou une dextérité extraordinaire, comme les ventriloques, les jongleurs les bateleurs; une infirmité suffit, comme pour les bossus, les borgnes, les aveugles, etc. [...]. C e qui leur donne des vertus magiques, cen'est pas tant leur caractère physiqueindividuel quel'attitude priseà l'égard de tout leur genre". M auss, M. Sociologie et Anthropologie. Paris: PUF, 1980, pp. 19-20. ${ }^{3}$ U ma situação nada excepcional, PAIVA, J. P., op. cit., 1997, p. 173.

${ }^{34}$ D e acordo com PAIVA, J. P., op. cit., 1997, p. 173: "não pode ficar-se com a idéia de que este universo era marginal, e se confinava a uma espécie de submundo de segregados sociais que apenas funcionava ocultamente e com o concurso de pouca gente". Assim, alguns curadores e feiticeiros deslocavam-se pelas feiras anunciando os seus serviços, mostrando 0 extraordinário poder de proteção de al guns dos seusamuletos. 0 utros, mais discretos, realizavam as suas demonstrações nas tabernas. pp. 168-169. 0 caso Francisco Antônio inscrevese entre os 207 processos para curas mágicas instruídos pela Inquisição entre 1700 e 1774, sendo os anos 1740-44 o período mais repressivo. pp. 207-225.

${ }_{35}$ Todas as classes sociais, médicos, boticários, nobreza, clero e mesmo os membros da Inquisição recorriam aos curandeiros e feiticeiros. Ibidem.

${ }^{36}$ BO U RD IEU , P. Uneinterprétation delathéoriedelareligion selon M ax Weber. Archives Européennes de Sociologie. XII, 1, 1971, p. 20.

${ }^{37}$ IAN TT, Inq. Lisboa, no 11.179, (4-9-1744).

38 D enúncia de Bárbara M ana, 4 de setembro de 1744.

39 "começaram a fazer sons com os dedos na mesma banca dois dos ditos pretos e o mas gordo cantava na sua língua coisas que el e testemunha não percebeu e o ajudavam a cantar os companheiros, o que repetirão por várias vezes". D epoimento do marido, José G omes, do 11 de setembro de 744 .

${ }^{40}$ Se há especificação das formas da magia de acordo com as sociedades, há, dentro de cada magia, ou, de um outro ponto de vista, dentro de cada um dos grandes grupos de ritos [... ] variedades dominantes. A seleção dos tipos é, em parte, a obra de mágicos especial izados que aplicam só um rito ou um pequeno número de ritos ao conjunto dos casos pelos quais são qualificados. C ada mágico é o homem de uma receita, dum instrumento, dum saco medicina, que ele utiliza fatalmente à qual quer propósito. É mais freqüentemente de acordo com os ritos que praticam que de acordo com os poderes que possuem, que os mágicos são especial izados. Acrescentemos que aqueles que chamamos os mágicos ocasionais conhecem ainda men os ritos que os mágicos como tais e são tentados de reproduzi-los sem fim [...] Vemos assim [...] quanto a forma tende a predominar sobre o fundo. M AU SS, M. Sociologie et Anthropologie. Paris: PU F, 1980, p. 53. 
${ }^{41}$ PAIVA, J. P., op. cit., 1997, p. 110.

${ }^{42} \mathrm{~A}$ cruz é um dos quatro símbolos fundamentais que se encontram na maior parte das culturas do mundo desde a mais alta antiguidade. $\mathrm{Na}$ África, tem em primeiro lugar um sentido cósmico. Simboliza igualmente os caminhos da vida eda morte, uma imagem do destino do homem. CH EVALIER J. \& GHEERBRAN T, A, op. cit., pp. 245-251.

43 "O sacerdote de Fá opera muito raramente só: mais é respeitado, mais tem discípulos. Assistem às consultas com o objectivo de instruir-see substituir o vidente no caso onde 0 cansaço, a febre, a apreensão, ou tal outra causa de perturbação mental prejudicaria o bom andamento da consulta". M AU PO IL, Bernard. La G éomancieà I'anci enneC ôtedesEsclaves. Paris: Institut d'Ethnologie, [1943], 1998, 3ạ ed. pp. 420-421. 0 material dessa obra foi recolhido em Abome e Porto N ovo entre 1934 e 1936.

${ }^{44}$ Idem, p. 143 e seguintes.

${ }^{45}$ AU GÉ, M arc. Le Génie du paganisme Paris: G allimard, 1982, p. 219. Sublinha que as descrições da "bruxaria" africana que pôde fazer «ao vivo» (através das confissões dos acusados, o rumor público ou os especial istas locais da cura e da contra feitiçaria) evocam de maneira bastantenotável aquelas que puderam recol her no seu tempo os inquisidores eos juízes; os temas do desdobramento, a metamorfose e a ambigüidade da rel ação feiticeiro/ contra feiticeiro, nomeadamente, apresentam sobreos dois continentes, em uma ea outra história, numerosas analogias.

${ }^{46}$ Para a França: T H IERS, Jean Baptiste. Traitédessuperstitions. Paris: LeSycomore, 1984, oferece para o fim do século XVII várias formulas já antigas: pp. 148, 158-167.

${ }^{47}$ Assim que declara José, 18 ou 19 anos, natural da Bahia, preso por estar de posse de uma mandinga: IANTT, Inq. Lisboa, Processo no 4.260, (1730).

${ }^{48}$ PAIVA, J. P. 0 p. cit., 1997, p. 114 eAN TT, Inq. Lisboa, Processo no 6.005, demonstrações em espaços públicos.

${ }^{49}$ IAN T T, Inq. Lisboa, Processo no 3.670, (1690).

${ }^{50}$ Ver igualmente, C ALAIN H O , D aniela Buono. M etrópole das mandingas. Religiosidade negra el nquis ção Portuguesa no Anti go Regime. Tese de doutoramento. N iterói, 2000, pp. 90 e 165; "Jambacousse e gangazambes: feiticeiros negros em Portugal", Afro-Ásia, 26-26 (2001), 141-146; N egros hereges, agentes do D iabo. Religi osidade negra e Inquisição em Portugal - Séculos XVI-XVIII. In: FLOREN TIN O, Manolo \& M ACH AD O, Cacilda (O rgs.), op. cit., pp. 65-83.

${ }^{51}$ PAIVA, J. P. O p. cit., p. 114; IAN TT, Inq. Lisboa, Processo no 3.670, (1690).

52 "As armas com que cobrem os corpos são uns camizões que Ihe fazem os feiticeiros, que entreelles não he defeso este crime, antes quantos maiores os são mais temidos erespeitados se fazem. Estes camizões Ihe cobrem todos os corpos the os pes e estão cheyos de bolcinhas de couro, que elles chamão nominas, em que poem papeis com caracteres, e dizem queisto defendedas armas deseusinimigos". CO ELH O, Francisco de Lemos. D uas descrições sei scenti stas da Guiné (1669 e1684). Lisboa: Academia Portuguesa da H istória, M CM XC, p. 108. 
${ }^{53}$ PAIVA, J. P., op. cit., 1997, p. 114.

${ }^{54} \mathrm{I}$ bidem.

${ }^{55}$ IAN TT, Inq. Lisboa, Processo no 11.767 (1731).

${ }^{56}$ M OTT, Luís. Etno-demonologia: aspectos da vida sexual do diabo no mundo ibero-americano (séculos XVI ao XVIII), citado por SO UZA, Laura de M ello e. 0 Diabo ea terra de Santa Cruz, Feitiçaria e religiosidade popular no Brasil. São Paulo: Companhia das Letras, 1986, p. 318, no qual analisa os dois processos pp. 299, 316-321 assim como em Inferno atlântico... pp. 170-172.

${ }^{57}$ PAIVA, J. P., op. cit., 1997, p. 156.

${ }^{58}$ SO U ZA, Laura de M ello e. O p. cit., 1986, p. 316.

${ }^{59}$ Será necessário perto de um ano para Francisco José Pedroso confessar as suas cul pas. É condenado a uma pesada penal idade de 5 anos na galé, ao porto perpétuo do sambenito, após ter saído em auto-de-fé público e de ter sido açoitado extra sanguinis effusionem.

${ }^{60}$ M OT T, L., “Ethno-demonologia”, citado in: SO UZA, Laura deM ello e. O p. cit., 1986, pp. 317-318.

${ }^{61}$ Esta banalidade surge de uma dúzia de processos compreendidos entre 1704 e 1771 dos quais a quase totalidade data do primeiro terço do XVIII. Banal, porque fabricantes, intermediários eutilizadores parecem não tomar muitas cautelas, o que as denúncias provam. Banais igual mente porque alguns donos nem denunciam o facto, enquanto outros as obtinham eles mesmos para as oferecer aos seus escravos. D ois casos deste tipo dizem respeito respectivamente a um cavaleiro da $\mathrm{O}$ rdem do C risto dos arredores de Lisboa ea uma mulher oriunda do Brasil recolhida num convento na fronteira norte de Portugal. IAN T T, Inq. Lisboa, Processo no 16.566 (1729) e 16.684 (1735). JoséFrancisco Pedroso usa este fato como argumentação da sua defesa: "D isse que elle entendia que a mandinga era cousa de D eos, porquel hechamavao oraçao, ecomo muitagentea trazianao Iheparecia ser couza do D emônio."

${ }^{62}$ Provavelmente a erva de Guiné, conhecida no Brasil como amansa-senhor. Envenena Ientamente, provoca a indiferença até a imbecilidade, fraqueza cerebral, pequenas convulsões tetaniformes, paralisia da laringe e, dependendo da dose, a morte ao fim de um ano.

${ }^{63}$ D urante a sua confissão Francisco Pedroso evoca em várias ocasiões o medo do castigo bem como o feitiço que o protegia das represálias do seu dono. Processo no 11.774: fls. 66-68 e 89-93.

${ }^{64} 1^{\circ}$ Exame. (fol. 32-36) 11 dejulho de 1730; 2ㅇ․ Exame. (fol. 37-42) 14 de julho de 1730. ${ }^{65}$ IAN TT, Inq. Lisboa, Processo 2.355 (1704). Jacques Viegas, guarda-costas, 20 anos. $\mathrm{N}$ ão faz referência aos dois tipos de bolsas mas insiste na proibição de aproximar-se de uma igreja para os que possuem aquela que eleusa. M esmo tipo deambivalência dos acusados: IANTT, Inq. Lisboa, Processo 4.260, (1730); Joseph, escravo de 18 anos; Inq. Lisboa, Processo 1.672, (1731). M iguel Vieira, 16-17 anos. 
66 "sob a aparência do bem o demónio engana mais os simples que, tendo realizado de santas práticas, pensam ter obtido al gum dom consagrado deD eus, enquanto queapenas cometeram pecados maiores". M alleus M aleficarum, p. 306.

${ }^{67}$ 2ㅇ. Exame, fls. 37-42, 14 de julho de 1731.

${ }^{68}$ Para o século XVI ver BET H EN CO U RT, F. O p. cit., p. 76, aponta as virtudes eróticosentimentais da pedra de ara esmagada eingerida. É querendo recuperar orações, escondidas sob a pedra de altar da capela privada do seu dono, que $D$ amião de Almeida faz-se surpreender em 1771. IAN TT, Inq. Lisboa, Processo 724, (1771).

${ }^{69} \mathrm{U}$ ma das características do pacto com o demónio.

${ }^{70}$ VASC O N CELOS, José Leite de. SALO M O N IS, Signum. A Figa - A Barba em Portugal. Lisboa: Publicações D om Q uixote, 1996, pp. 49-162. Esteensaio publicado em 1918 apresenta 240 grafismos diferentes deste símbolo conhecido como sino-saimão.

${ }^{71} \mathrm{U}$ ma parte das orações e dos desenhos deste processo foi publicada, em preto ebranco, na obra de Laura de M ello e Souza, op. cit., 1986, na parte "D ocumentos", e, a cor, pp. 162-163 In: DIDIER, Lahon; N ETO, M aria Cristina et alii. C atálogo da Exposição Os N egros em Portugal - Sécs. XV a XIX. Lisboa: M osteiro dos Jerónimos de Belém, 23-91999/24-1-2000, C.N.C.D.P., Lisboa, 1999.

72 " $†$ vos $\uparrow$ salve asucena deres plandesente esempre mil Trindade $\|$ eos $\dagger$ vos calve $\dagger$ rosa florida eterna primavera D eos vos \\ [1palavra] exsellentisima † rainha $†$ dos seos cheya $†$ de inumera $\| †$ estina foy esorro gastucas o virgem † santisima † dapen[.] II ?† Bendita

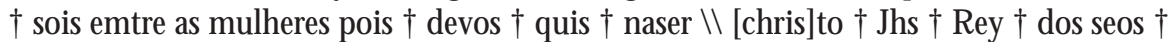
eresplandor $\dagger$ dagloria eser alimenta $\|$ vosos $\uparrow$ perto dovoso $\uparrow \|$ purisimo alimento $\dagger$ vos

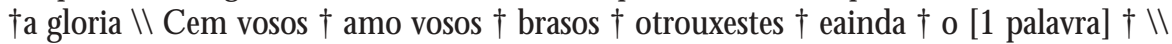

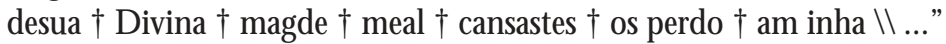

${ }^{73}$ BETHEN COU RT, F., op. cit., p. 112.

${ }^{74} \mathrm{O}$ processo do mulato $\mathrm{M}$ anoel $\mathrm{M}$ atheus, $\mathrm{O}$ Saramago dealcunha, suspeito deusar uma mandinga, revela até onde conduzia a credulidade compartilhada pelos representantes da ordem religiosa e civil sobre os poderes de tais bolsas. Em 1711, acusado de assassinatos, ele resiste com a espada no punho a sua detenção por vários representantes da justiça e nem fica ferido com trêstiros de pistolas à queima-roupa. U mavez dominado recebeuma sova de golpes de espadas no curso da qual uma espada e um pau de madeira são-Ihes quebrados sobre o corpo. N o entanto uma vez na prisão, para a maior admiração dos testemunhos, não revela nenhuma ferida sangrenta. 0 Juiz de fora considerou "que pella experiencia que tem de outras prisoes que tem feito Ihe parecia empossivel deixar de lançar sangue, que so tendo mendigas ou pacto com o demonio poderia o não ser ferido". Inquietos, os actores da detenção voltaram a mesma noite à prisão para sujeitar o prisioneiro à uma experiência: "fora elle ditto juiz de fora elhemetera huma faca de ponta num braço para fazer a experiência se tinha ou não mendiga do qual experiência metendo lhe duas vezes a faca com bem força não tirou sangue algum, e só amolgara a carne". M anoel não confessou usar uma mandinga mas admitiu invocar o diabo quando agarrava a sua espada. A pósa audição dosoito testemunhos da cena, queasseguraram ter-lhelevado gol pes 
de espadas e pistolas mortais ao estômago ou ao pescoço, o tribunal considerou os testemunhos dignos de fé. IAN TT, Inq. Lisboa, Processo 11.801.

75 "A cotovia, pela sua maneira de se elevar muito rapidamente no céu, ou, ao contrário, de se deixar bruscamente cair, pode simbolizar a evolução e involução da M anifestação. As suas passagens sucessivas da terra ao Céu e do Céu à Terra ligam os dois pólos da existência: ela é uma espécie de mediador. [...] Ave sagrada para os $G$ auleses, permanece ao longo da história do folclore e das crenças populares francesas uma ave de bom agouro, entrando por vezes mesmo na composição dos talismãs[...]" tornando vitoriosos tanto os homens como os elementos. CH EVALIER J. \& GHEERBRANT, A., op. cit., p. 236. $\mathrm{N}$ ão encontramos um equivalente português a esta crença mas não se pode ignorar esta coincidência. $N$ ão temos encontrado uma lenda africana equivalenteà da cotovia. $N$ a região da Costa dos Escravos, de acordo com as lendas referida por M AU POIL, B. op. cit., p. 508, a cotovia não faz parte das "aves feiticeiras".

76 BETHEN COURT, F., op. cit., p. 167. É igualmente ao Vale de Cavalinho que ia $M$ arcelina M aria durante as suas deslocações nocturnas, IAN TT, Inq. Lisboa, Processos no 631 (1734) eque, em 1771, D amião de Almeda enterrava suas mandingas cujas orações continham igualmente o sino-saimão, claramente identificado por vários testemunhos. IANTT, Inq. Lisboa, Processos no 724.

${ }^{77}$ Conhecido hoje como o bairro da M adragoa. Era o equivalente ocidental do bairro de Alfama ao leste de Lisboa. Ambos muito populares, situados perto das beiras do Tejo, povoados de numerosos pescadores.

${ }^{78}$ Confissão (fol. 89 à 93), 11 de maio de 1730.

79 SO U ZA, Laura de M ello e. Op. cit., 1986, pp. 320 e 261

80 M AU PO IL, B., op. cit., p. 363.

${ }^{81}$ I dem, 2a parte, cap. II, os símbolos mais importantes e suas mensagens, pp. 430-676 e pp. 534-36; epp. 604-605, para as lendas relativas ao bode.

${ }^{82}$ M ET RAU X, A., salienta a importância na escol ha da vítima: "O animal éagradável ao D eus apenas se responde aos seus gostos eapresenta alguns dos seus atributos". LeVaudou H aitien. Paris: Gallimard, 1958, p. 151.

${ }^{83}$ M AU PO IL, B., op. cit., p. 76, ep. 84 para o culto das encruzilhadas.

${ }^{84}$ VERGER, P. Fatumbi. Les D ieux Yoruba en Afrique et au N ouveau M onde. Paris: Ed. M étailié, 1982, pp. 74 e 76. Pruneau de Pommegorge, comandante da fortaleza francesa em Ajuda entre 1743 e 1765, descreveuma representação do tamanho de um homem de "um D eus Priape, grosseiramente feito em terra com o seu principal atributo, enorme e exagerado, à proporção do resto do corpo". PO M M EG O RGE, Pruneau de. D escription de la N igritie. Amsterdam-Paris, 1789, p. 201.

${ }^{85}$ M AU POIL, B., op. cit., p. 677.

${ }^{86}$ Idem, p. 80.

${ }^{87}$ I bidem.

${ }^{88}$ VERGER, P. Fatumbi. Op. cit., p. 74. 
${ }^{89}$ M AUPOIL, B., op. cit., p. 81.

${ }^{90}$ Idem, p. 82.

${ }^{91}$ Esta moça (ogo), teria a virtude, preciosa para um mensageiro, de transporta-lo em algumas horas a centesnas dequilômetros. VERG ER, P. Fatumbi. D ieux d'Afrique. Ed. Revue N oire, 1995 (1a Ed.1954), p. 258. Tem por conseguinte a mesma função, entre outras, que a "vassoura" tradicional e popular da bruxa que permite tran sportar-se ao sabá.

92 Idem, pp. 162-165 eVERGER, P. F., op. cit., 1982, pp. 132-138.

${ }^{93}$ Para os Fons e Ayizos do Benim, H èviosso, a divindade do trovão é representada igualmente por uma pedra de raio e um machado, mas deum gumesó. VERG ER, P. Fatumbi. O p. cit., 1995, pp. 180-182. Em Verger e M aupoil, H éviosso é acompanhado de um Panteão de uma dúzia de divindades, cada uma com a sua atribuição. M AU PO IL, B., op. cit., p. 73, das quais Avrékété, de carácter malicioso, indiscreto e escabroso.

${ }^{94}$ VERGER, P. F., op. cit., 1995, pp. 162-163. Sobre a significação de ara; BEN ISTE, José. Ò run Àiyé, 0 en contro de doi s mundos. 0 si stema de relacionamento nagô-yorubá entre o céu e a terra. Rio de Janeiro: Bertrand-Brasil, 1997, p. 124.

${ }^{95}$ CHEVALIER, J. \& GHEEBRAN T A., op. cit., pp. 347-348.

${ }^{96}$ M AU PO IL, B., op. cit., p. 104. N a divinação de Fá, o gato é relacionado com o signo deSa-M eji, quemanda o sangue. 0 quecorrespondea umadas virtudes atribuídas à bolsa. 97 "Armes des $\mathrm{N}$ ègres de la Côte d'O r tirées de Barbot", Abbé Prevot, H istoi regénérale des voyages. Paris: Didot, 1746, T. IV, pl. VI, p. 100, reproduzida por ISERT, Paul Erdman, Voyages en Guinée et dans lesîles C araïbes en Amérique. Paris: Karthala, 1989, gravura 7. ${ }^{98}$ M ÉT RAUX, A. O p. cit., pp. 66-67. Poteau-M itan: não há tradução em Português. E a coluna central num templo vodu, ao redor do qual os rituais são realizados. In: G lossário de M agia e Esoterismo, São Paulo: N ETRA, 1a edição, 2001, p. 105.

${ }_{99}^{9}$ Figura 1: capa da obra deAU GÉ, M arc. LeD ieu O bjet. Paris: Flammarion, 1988; Figura 3: capa da obra deCAPO N E, Stefania. La quêtedel'Afrique danslecandomblé, Pouvoir et tradition au Brésil. Paris: Karthala, 1999; Figura 4, foto 1, "Assento del'Exu du portal, em barro, com os traços antropomorfos", entre as páginas 224 e 225 da mesma obra. 100 MÉTRAUX, A. O p. cit., p. 98.

${ }^{101}$ Idem, p. 26.

102 M AUPOIL, B. Op. cit., p. 66.

${ }^{103} \mathrm{O}$ s Estados U nidos importaram 650.000 escravos africanos. Consideramos que não foram menos de 400.000 os que entraram em Portugal entre 1441 e 1761. Estimativa que corresponde à de 800.000 para a Péninsula I bérica inteira feita por ST ELLA, Alessandro. H istoires d'esclaves dans la Péninsule l bérique. Paris: EH ESS, 2000.

${ }^{104}$ Adotamosa definição deSALLM AN N , Jean-M ichel. N apleset sessaintsá l'âgebaroque (1540-1750). Paris: PU F, 1994: "Situar-se do único ponto de vista da instituição quejulga conduz a privilegiar critérios de classificação demasiado restritivos. É uma posição que proíbe qualquer abordagem de tipo antropológica na medida em que esta santidade ofi- 
cial constitui apenas uma fraca porção de um fenômeno social muito mais largo (...). É santo qualquer indivíduo que foi tido como tal pelo grupo no qual evoluiu" p. 123. Para nosso propósito ver: Breve compendio da vida, e acções virtuosas do veneravel servo de D eos, Fr. António da Concei ção, vulgarmente chamado Fr. Antonio do Lumiar, (... ). D ado a luz por A pollinario de Freitas $\mathrm{C}$ ardozo. Lisboa, $\mathrm{O}$ ff. de Francisco Borges de Sousa, anno de 1763. Com todas as licenças necessárias.

${ }^{105}$ PAIVA, J. P., op. cit., 1997, p. 174. Pelo povo o recurso aos curandeirose feiticeiros era provavel mente mais imediato e constante em razão duma maior proximidade social. As pessoas de maior prestígio apenas recorriam aos curandeiros depois de terem esgotado as possibilidades junto dos médicos e da I greja.

${ }^{106}$ T H IERS, J. B., op. cit., p. 265; a impotência por causa de feitiçaria que "éum mal tão sensível à maior parte dos que sofrem dele, que não há nada que não façam para ser curados. Q ue seja D eus, ou o D iabo que os livra, é de qual ficam pouco afligidos, desde que forem libertados". ParaLEBRU N , François. M édecins, saintset sorciersaux 17eet 18esi ècles. Paris: M essidor, 1983, p. 127, nota 48, esta observação vale para todas as doenças.

${ }^{107}$ Todas as categorias sociais, inclusive os escravos, são representadas, com excepção da nobreza.

${ }^{108}$ As sangraduras real izavam-se perto da sede do mal. LEBRU N , F., op. cit., p. 63

${ }^{109} O$ caso aparenta-se a um processo de profecia negativa em relação ao desejo formulado por um casal que não consegue ter filhos. Pede ao Provincial do convento da Arrábida de fazer-Ihes chegar um cinto de corda utilizada pel o santo homem. Esteúltimo entregando o cinto ao portador recomenda-Ihequetransmita mensagem seguinte: "previnequeaquilo não fará nada". 0 que se confirmou mais tarde.

${ }^{110}$ LEBRUN , F., op. cit., p. 122.

${ }^{111}$ O rdem H ospitalar fundada pelos devotos de Sto Antão, anacoreta egípcio, c. 251 - 356.

112 Santo Antônio, São Sebastião, João Baptista e João o Evangelista.

${ }^{113}$ GIL, José. M étamorphoses du Corps. Paris: La Différence, 1985, p. 202.

${ }^{114}$ BEN ESCH , 0 tto. La peintureallemande, de D ürer à H ol bein. G enève: Skira, 1966, p. 87; GIL, J., op. cit., p. 202

115 GIL, J., idem, pp. 202-203.

${ }^{116}$ Sobre a relação santidade medicina ver: SALLM AN N , J. M ., op. cit., p. 375.

${ }^{117}$ Idem, pp. 357 e 356.

${ }^{118}$ Sobre a criminalização dos actos de bruxaria ver: PAIVA, J. P., op. cit., 1997, pp. $192-$ 197; BETH EN COURT, F., op. cit., pp. 230-231.

119 PAIVA, J. P. op. cit., 1997, pp. 103 e 173.

120 Idem, p. 174. Confissão feita entre 1754-58.

121 "II n'y a donc pas de raison pour mettre en doute l'efficacité de certaines pratiques magiques", LEVI-ST RAU SS, C., Anthropologie Structurale, Chap. "M agie et Religion", pp. 184-185. 
122 p. 218. Sendo muita conhecida a sua análise comparativa entre cura xamanista e cura psicanalítica apenas citaremos a sua conclusão: "En fait, la cure chamanique semble être un exact équival ent dela curepsychanalytique, mais avec une inversion detouslestermes. Toutes deux visent à provoquer une expérience; et toutes deux y parviennent en reconstituant un mythe que le malade doit vivre, ou revivre. $M$ ais dans un cas c'est un mytheindividuel quelemaladeconstruit àl'aide d'élémentstirés de son passé; dansl'autre, c'est un mythe social, que le malade reçoit de l'extérieur, et qui ne correspond pas à un état personnel ancien. Pour préparer l'abréaction qui devient alors une "adréaction", le psychanalyste écoute, tandis que le chaman parle. M ieux encore: quand les transferts s'organisent, le malade fait parler le psychanalyste en lui prêtant des sentiments et des intentions supposées; au contraire, dans l'incantation, le chaman parle pour (le) malade. II l'interroge, et met dans sa bouche des répliques correspondant à l'interprétation de son état dont (il) doit se pénétrer". p. 220.

${ }^{123}$ LEVI-ST RAU SS, C. AnthropologieStructurale, op. cit., cap. IX, "Lesorcier et saM agie", pp. 184-185.

124 "C ompreende-senestas condições, a importância da fé, a esperança colocada pelo pacientee seus familiares na intercessão do santo ea ajuda sobrenatural (...) constitui verdadeiramente a cavilha operária da cura miraculosa, um verdadeiro condicionamento psicológico em redor do qual o paciente reorganiza as suas defesas. Pelo contrário, é fácil imaginar que, quando o santo prediz a morte próxima do paciente, acelera o seu desmoronamento e o conduz inevitavelmente ao túmulo." SALLM AN N , J. M ., op. cit., p. 361.

125 I dem, p. 366. Sobre "o lugar específico do santo cristão e o milagre na nebulosa cultural dos xamanismos" ver pp. 235-236; 356-367; 372-374. Sobre 0 efeito de predição: SCH UTZEN BERG ER, AnneAncelin. FormeEuropéenneinconscientedu Chamanisme: $L$ a réalisation automatique des prédictions. Transe, chamanisme, possession. Actes des IIe rencontres Internationales de N ice, Avril, 1985, N ice: Editions Serre, 1986, pp. 81-87.

126 PAIVA, J. P., op. cit., 1997, p. 172.

127 Idem, pp. 104 e 169.

128 "Assim funcione (...) um sistema mágico que cristalize os medos humanos sobrea bruxa local e que evacua estes mesmos medos pelo recurso aos curandeiros externos". 0 estrangeiro quequebra o malefício, vindo do mundo exterior, «possui a força desconhecida e desconcertante". M U CH EM BLED, R., op. cit., pp. 101-102.

${ }^{129} \mathrm{~J}$ oaquim, escravo da C osta da M ina, pretende ter o poder defazer adoecer as pessoas e numerosos testemunhos confirmam as suas al egações. Ameaça matar uma mulher branca se ela não Ihe escrever uma oração num pedacinho de papel. Aterrorizada, ela executa-se. Alguns meses depois o dono de J oaquim "o faça embarcar" - o que significa que o vende, provavelmente para o Brasil - porque suspeita queele seja responsável pela mortedas suas duas filhas. Sendo culpada pelos seus familiares e a vizinhança de cumplicidade com 0 escravo, a mulher quetinha copiado o bilhete sob ameaça vai reclamar justiça e protecção à Inquisição. IAN TT, Inq. Lxa, D enúncias, Liv. 313, (30-3-1759), fls. 41 e 94.

${ }_{130} \mathrm{M}$ aria da Conceição, natural da C osta da M ina, escrava de um marinheiro, denuncia um forro que a enganou fazendo-Ihe praticar, contra o seus donos, desastrosos sortilégios 
teoricamente destinados a melhorar a sua situação na casa. D e facto o dono vem a falecer e a sua esposa adoece gravemente. $M$ aria da $C$ onceição protesta da sua boa fé, dizendo que foi enganada pelo "preto que é Ladino enquanto ela chegou desde pouco tempo". IAN TT, Inq. Lxa, D enúncias, Liv. 313, (21 de junho de 1756), fl. 71.

${ }^{131}$ Aludimos à aplicação da cláusula de limpeza de sangueaos negrose mulatosa partir do início do século XVII atéo início do século XIX - apesar da lei de 1773 - , objeto denossa pesquisa actual.

132 "Se buscaban curanderos dentro de los grupos raciales diferentes al del paciente, y esa diversidad fortalecio las redesterapéuticas hastanuestros dias: en el Ecuador, por ejemplo, un indigena de la sierra ecuatoriana buscará de preferencia a un negro de la costa, un moreno, a un mestizo o a un blanco, un blanco, a un indio... El éxito de las curaciones depende de esta complementaridade. En todo caso fue en torno de la aflicción que se tejieron vínculos entre los tres grupos en presencia, españoles, indios y africanos". pp.1819; “En la N ueva España, SolangeAlbero ha puesto en evidencia un esquema muy frecuente del funcionamento de estas redes: la india es quien proporciona las sustancias - hierbas, pociones, piedras - y las españolas lo recibe por medio de la negra o de la mulata. El campo marginal y clandestino de la magia es el que permite a las castas la función social de intermediario (...)". BERN AN D , Carmen. N egrosesclavosy libresen las ciudadesamericana. In: CD -Rom Colección Proyectos H istóricosTavera (I). M adrid: DIGIBIS, 2000, pp. 18-19 e p. 20.

\section{Resumo}

No início do século XVIII a escravidão chegou ao seu apogeu em Portugal, especialmente em Lisboa. Até 1761, um milhar de cativos africanos, ou mais talvez, por ano, desembarca no cais da capital. Vêm diretamente da África ou do Brasil onde residiram alguns anos. Começa para eles um longo processo de adaptação, de reconstrução da identidadee do imaginário. Por detrás dafachada das seteconfrariasnegras, entreas quais duas eram de nações, que apresenta a versão oficial e enquadrada no catolicismo barroco e procura produzir e apresentar negrosà alma branca, se esconde uma outra realidade: a persistência das crenças africanas tradicionais, articuladas ou misturadas às tradições populares portuguesas, às quais, respondendo à sua procura de poderes mágicos diferenciais e cumulativos, as populações brancas mostram-sesensíveis. 0 s processos da Inquisição revelam assim que feiticeiros, mágicos, mandingueiros e curandeiros negros inserem-se, cada um à sua maneira, na cadeia complexa dos agentes legítimos e il egítimos do sagrado.

Palavras-chave: Lisboa século XVIII; M agia; Calundu 


\section{Abstract}

At the beginning of century XVIII, the slavery arrived at its apogee in the PortugueseM etropolis, especially in Lisbon. Until 1761, athousand captive Africans, or more perhaps, per year, disembarks in the wharfs of the capital. They come directly of Africa or Brazil where someyears had inhabited. A long process of adaptation, reconstruction of the identity and of the imaginary onestarts for them. Behind frontage of seven black brotherhoods, between which two were of nations, which presents theofficial and framed version of baroque $C$ atholicism and seek to produce and to present blacks with a whitesoul, appears another real ity: thepersistence of the traditional African beliefs, articulated or mixed to the Portuguese popular traditions, to which, answering to its search of magical cumulative and differentials powers, the white populations reveal sensible. Thus, the Inquisition trials disclose that, mandingueiros, soothsayers, wizards, and black magical folk healers insert themselves, each one with its manner, in the complex chain of legitimated and illegitimated agents of the sacred.

Key-words: Lisbon; slavery; black magicals 